\title{
Archaeological Investigations at the San Pedro Aceqnia San Antonio, Texas
}

Augustine J. Frkuska Jr.

Follow this and additional works at: https://scholarworks.sfasu.edu/ita

Part of the American Material Culture Commons, Archaeological Anthropology Commons, Environmental Studies Commons, Other American Studies Commons, Other Arts and Humanities Commons, Other History of Art, Architecture, and Archaeology Commons, and the United States History Commons

Tell us how this article helped you.

This Article is brought to you for free and open access by the Center for Regional Heritage Research at SFA ScholarWorks. It has been accepted for inclusion in Index of Texas Archaeology: Open Access Gray Literature from the Lone Star State by an authorized editor of SFA ScholarWorks. For more information, please contact cdsscholarworks@sfasu.edu. 


\section{Archaeological Investigations at the San Pedro Aceqnia San Antonio, Texas}

Creative Commons License

(c) (i) (8)

This work is licensed under a Creative Commons Attribution-NonCommercial 4.0 International License 


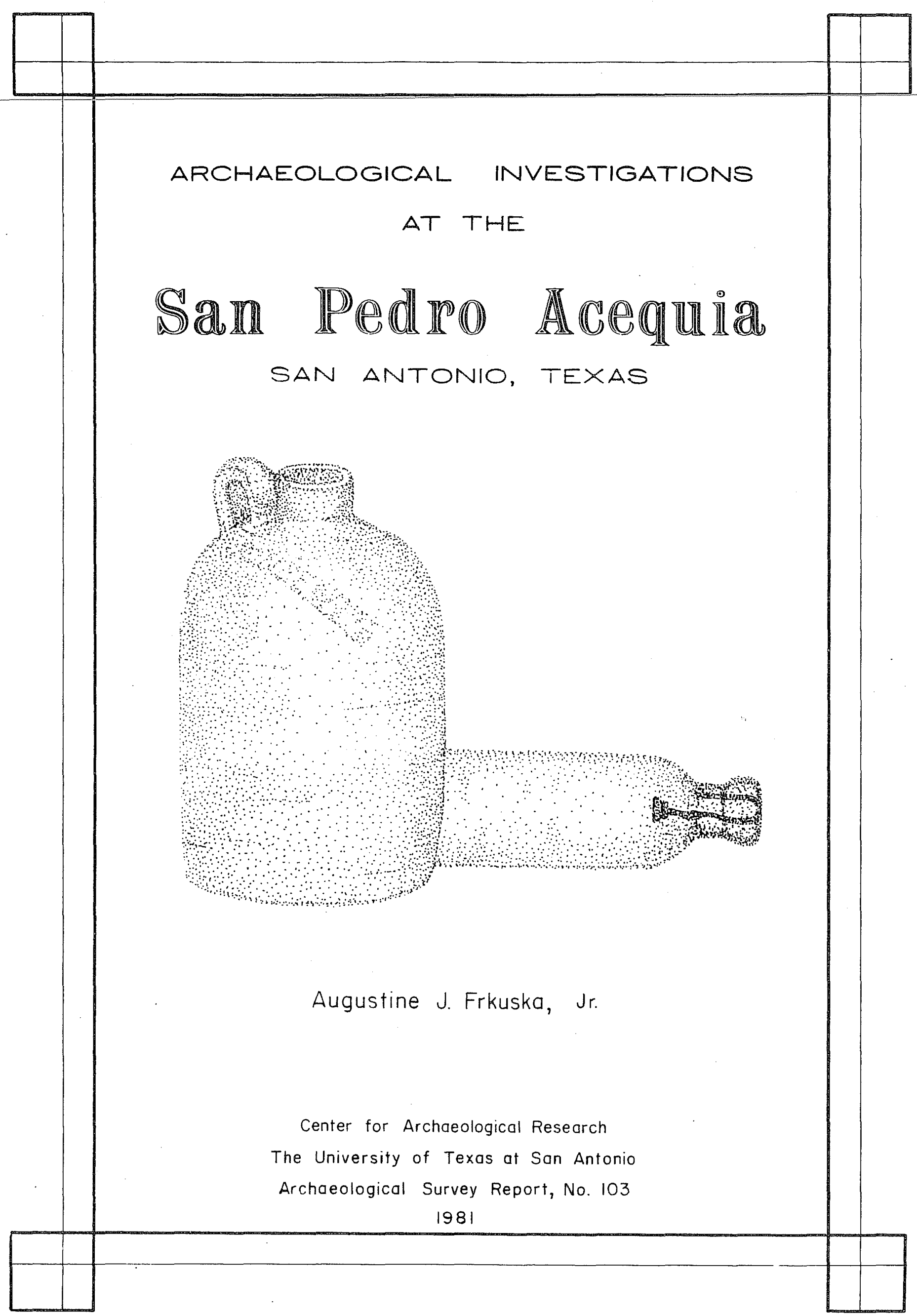



ARCHAEOLOGICAL INVESTIGATIONS OF THE

SAN PEDRO ACEQUIA, SAN ANTONIO, TEXAS

Augustine J. Frkuska, Jr.

Center for Archaeological Research

The University of Texas at San Antonio

Archaeological Survey Report, No. 103

1981 



\section{ABSTRACT}

The irrigation system in San Antonio was an integral part of its early history. Within the San Antonio area irrigation was a necessity to extend the planting season. An extended planting season would allow for diversified crops with different harvesting periods. The first municipal irrigation system was the San Pedro Acequia. It was constructed to serve the town with fresh water for household use and agricultural purposes. As the population increased and technology improved, the acequias changed in both appearance and function. In time, the San Pedro Acequia system became part of San Antonio's forgotten past.

Recently, excavations on the Government Service Administration (GSA) property in downtown San Antonio unearthed portions of the San Pedro Acequia. Investigations revealed the Acequia underwent three construction phases within the (GSA) property. Results of the archaeological investigations and 1 iterature research gives a vivid picture of the history of the San Pedro Acequia. 

TABLE OF CONTENTS

Page

Abstract ...................... ${ }_{i}$

List of Figures. . . . . . . . . . . . . . . . i i

Introduction ...................... 1

Setting. ..................... 1

Historical Sketch..................... 1

Previous Archaeological Research . . . . . . . . . . . . . 7

Test Trench Observations ................... 7

Observation Phase I............... 9

Observation Phase II. . . . . . . . . . . . 14

The Artifacts. . . . . . . . . . . . . . . . . . 29

Conclusions. . . . . . . . . . . . . . . . . . . 45

Recommendations. . . . . . . . . . . . . . . . . 46

Acknowledgments. . . . . . . . . . . . . . . . . . . 47

References Cited..................... . . 48 



\section{LIST OF FIGURES}

Figure

1. Map of the San Antonio Area Indicating the Locations of Previous Archaeological Investigations of Spanish Colonial Acequias . . . . . . . . . . . . . . 8

2. Plan of General Services Administration Property Indicating the Locations of Test Trenches and the Routing of the San Pedro Acequia . . . . . . . . . . . . . . . 10

3. Soil Profiles Showing the San Pedro Acequia from Phase I. . . . . . 13

4. Soil Profile of Trench B. . . . . . . . . . . . . 15

5. Soil Profile of Trench C................ 16

6. Soil Profile of Trench D. ............... 18

7. Soil Profile of Trench F Showing Masonry Work on Acequia. . . . . . 20

8. Soil Profiles of Trench I and Trench J. . . . . . . . . . . . 21

9. Soil Profiles of Trench M and Trench N. . . . . . . . . . . . 24

10. Soil Profiles of Trench 0 and Trench P. . . . . . . . . . 26

11. San Pedro Acequia . . . . . . . . . . . . . 27

12. Selected Pharmaceutical Artifacts from the San Pedro Acequia. . . . 38

13. Selected Glass Containers ................ 39

14. Selected Glass Artifacts Using Seam Height as a Time Period Indicator . . . . . . . . . . . . . . . . 40

15. Selected Metal Artifacts. ................ 41

16. Selected Glass Artifacts. . . . . . . . . . . . . . 42

17. Selected Ceramic Artifacts. . . . . . . . . . . . . . 43

18. Selected Metal Artifacts. . . . . . . . . . . . . . . . 44 


\section{.}




\section{INTRODUCTION}

In November 1979, the Center for Archaeological Research (CAR), The University of Texas at San Antonio (UTSA), carried out archaeological investigations of property located south of the old U.S. Arsenal in downtown San Antonio. This work was conducted under contract with the Construction Management Division of the General Services Administration (GSA), order number 14866382, dated October 18, 1979.

Earlier Phase I investigations of this GSA property were carried out in June 1979 (Valdez and Eaton 1979) in order to determine whether or not the Spanish Colonial San Pedro Acequia ran through the property. Two portions of the acequia were uncovered by these investigations. As a result of these tests, additional study was recommended. The current work, Phase II of the investigations, was initiated in order to more precisely document the routing of the acequia prior to future development of the property by the GSA. The Phase II field work was done by Augustine Frkuska, Jr., with assistance of Waynne Cox and Harvey Smith, Jr. Dr. Thomas R. Hester, Center Director, and Jack D. Eaton, Associate Director, provided overal1 supervision of the project. In addition to the field work, extensive literature research was done for the study area. This research is by no means exhaustive, although enough information was collected to document and form interpretations of the archaeological work in Phases I and II. A study of the San Pedro Acequia has presented a clearer picture of what once was an integral part of the history of San Antonio.

\section{SETTING}

The General Services Administration property is located between two major drainages. The San Pedro Creek flows south and lies to the west of the GSA property, and the San Antonio River, which also flows south, lies to the east of the property. Across the GSA property, the land is flat with a gentle slope toward the south. At present, the area is parkland covered with grass and a large number of pecan trees are dispersed throughout the park, along with a few live oaks, elms, and palms. Buildings once stood along the west side of the property fronting S. Flores Street. The locations of these buildings are marked by concrete and tile slabs which posed a problem for locating test trenches along the predicted route of the acequia.

The city blocks that were investigated by the CAR include NCB 2547, 2548, 2553, 2552, and 2969. The GSA property lies south of the Bexar County Courthouse and the old U.S. Arsenal, and between S. Flores Street and Main Street. Sheridan Street forms the northern property while W. Guenther Street forms the southern boundary.

\section{HISTORICAL SKETCH}

In 1718 Spanish missionaries and soldiers arrived at San Pedro Springs to begin the first significant European settlement, which later became known as San Antonio. Among their major concerns was the availability of water in a semiarid environment. This obstacle was overcome by a plan to construct a system of acequias (water ditches) to irrigate their farm lands (Castañeda 1936:96). Historic information is sparse about which acequia was dug first or its exact 
location. Valdez and Eaton (1979:1) suggest that the acequia known as the San Pedro Acequia originated from a series of channels constructed at San Pedro Springs by a few early settlers prior to 1718. However, the first major acequia constructed is conceded to be the Acequia Madre for the Mission of San Antonio de Valero. A historical sketch of missionaries and soldiers in relationship to the early San Antonio settlement can be reviewed in Fox, Bass, and Hester (1976).

The Canary Islanders arrived in March of 1731 and found five missions established in the area. Three of these missions were inaugurated just four days before the Islanders arrived (Holmes 1962:12). The Islanders, who were given the title of Hidalgos, saw the natives as a cheap work force for field work and irrigation projects. The Franciscans in the established missions thought of the Islanders as unwanted competition as well as a disturbing element for the natives. The friction between the two groups on a number of issues is wel1 documented throughout the Bexar County Archives (Buck 1949: Bolton 1915).

The settlers were commissioned to create a municipal government and to be assigned 1and with water rights (Buck 1949:94). The land and water rights were to be made permanent after an irrigation canal was dug. The Presidio de Bexar (Military Plaza) and San Fernando Church (Plaza de las Islas) were to become the center for the newly founded municipality (Cox 1899:217; Eaton n.d.). A description of houses and ownerships around "Plaza de Armas" can be reviewed in Chabot (1931). The acequia was to provide water to the town as well as to individuals' property along the way. Unfortunately, the construction of the acequia was delayed, since building homes and planting crops consumed a great deal of the Islanders' time.

Glick (1972:27) states that as few as seven of the group knew the fundamentals of irrigation. Antonio Rodriguez of Gran Canaria Island apparently was one of the knowledgeable members. Father Benito Fernandez de Santa Ana, head of the newly inaugurated missions, asked Rodriguez to supervise work on the construction of the Concepcion Acequia (Holmes 1962:23; Glick 1972:40; Buck 1949:177). It is possible that Antonio Rodriguez was the only irrigation engineer in the settlement, and the eventual removal of Rodriguez from the municipal work force could have been an additional reason for the long delay in the construction of the San Pedro Acequia.

The actual digging of the San Pedro Acequia did not start until 1738 (Arneson 1921:124). Buck (1949:179) writes about the large celebration at San Pedro Springs where the acequia was to draw its waters. The acequia would then extend to the Presidio, running in front of San Fernando Church, and on to the labores (fields). Records of when the water came through the Villa de San Fernando are vague. The lands north of the Villa were to have been watered by 1740 (ibid.). Glick (1972:40) recites an early document where the working water system of Villa de San Fernando in 1750 is used as an argument for the development of irrigation on the San Xavier River. The exact time the acequia reached the lands south of the Villa is still speculation. When the acequia was completed it was said to have been six feet wide, two feet deep and four miles long, and irrigated some 400 acres (Arneson 1921:124). 
The years 1740 through 1760 were a time of devastating Indian raids by the Apaches and Comanches (Ramsdel1 1959:22; Tunnel1 and Newcomb 1969:157). The upkeep of the acequia became a precarious affair, especially the areas away from the protection of the Presidio. This can be seen in the early laws governing the upkeep and the usage of the acequia system. These first laws were included in a document called "Laws of the Indies." They simply stated that each user pledged to keep his part of the acequia clean, repair the gates, and be in readiness to fight off any of the King's enemies (Arneson 1921:128; Buck 1949:179). Very few other ordinances were made by the municipal government. This can be attributed to the solidarity of the users of the canal, and this solidarity can be directly attributed to the needs of the times. For instance, every February was the time set aside to have all the farmers clean out the acequias (Arneson 1921:129). The settlers, no doubt, found strength in numbers while in the fields during the cleaning period.

Orders from Spain were issued in May of 1773 to close the presidios and missions of East Texas. Families from Los Adaes and Los Ais were relocated to the Villa de San Fernando (Bolton 1915:385). The Upper Labor Ditch was begun in 1776 at the head waters of the San Antonio River and irrigated the "Labores de Adeaseños" by the year 1778 (Holmes 1962:57). With the Upper Labor Ditch, the 1and and water under the municipal authority governing the irrigation system had doubled. The same regulations concerning the San Pedro Acequia now governed the Upper Labor Ditch.

Secularization of the mission lands came in the last quarter of the eighteenth century. Each mission had its own farmland and irrigation system that would come under the control of the municipality. The lands were divided between the Indians of the missions, the soldiers of the Presidio, and the settlers of the town (Broussard 1967:5). The authorities that once governed the San Pedro Acequia and Upper Labor Ditch now had miles of irrigation ditches on both sides of the San Antonio River to regulate. Apparently, the distance between the authority and the mission acequias was too great. Dobkins (1959:121) writes that the farmlands south of the city once cultivated by the missions were in wilderness as early as 1840 .

The beginning of the nineteenth century brought outside influence to the Spanish town. The Louisiana Purchase of 1803 brought westward movement of English speaking people and pressure towards independence. In September of 1810, Father Miguel Hidalgo started a revolutionary movement in Mexico that brought refugees into the northern part of Mexico (Ramsde11 1959:27). These refugees also brought stories of independence. However, the taste of independence in San Antonio was bitter. The next few decades were devastating to the San Antonio area. The unstable political climate was to have a long term effect on the acequias in general, and many of the town's prominent people were forced to flee. This depopulation of the town and the severe flood of 1819 brought the San Pedro Acequia watering efficiency to its lowest level since its construction (Ramsdell 1959:30). This is shown through an official complaint issued to the city council from the "Labors de Abajo" in 1822. The complaint stated that the city was not doing its share in the upkeep of the San Pedro Acequia (GTick 1972:46).

Texas, under newly independent Mexico, began to grow through the efforts of Moses Austin in his quest to colonize Texas with Americans. The colonization was rapid and Mexico became weary of its changing frontier. The question of 
independence was brought forth again and San Antonio would be the main recipient of the hardships in the struggle. Very little is said about the actual role the acequias had during the struggle for the independence of Texas. However, recent excavations at the Alamo by the Center for Archaeological Research may provide needed information for this time period. The Mexican miljtary in the early 1840s under Vasquez and Woll drained San Antonio of some of its citizens and city records (James 1938:19; Broussard 1967:27). Taken along with the city records were land titles with their water rights. The population dropped from 800 in 1839 to 600 in 1843 (Broussard 1967:27). Obviously, neglect played a destructive role during this time span on the acequia.

An interesting incident happened in 1840 involving the San Pedro Acequia. In her memoirs, Mrs. Mary Maverick (1921) writes of a Dr. Weidemann who, for purposes of medical study, took cadavers of several Comanches killed in the March 19, 1840 Council House fight. Dr. Weidemann emptied his soap boiler containing the Indian remains into the San Pedro Acequia, and when the citizens found out about it the next day, they had the doctor arrested. It is said that the doctor simply paid a fine and went away laughing. The fine was paid for the defiance of a city ordinance forbidding contamination; the ordinance being among the first to be passed by the municipality. The vigorous response by the citizens and the levying of the fine demonstrate the importance of the acequia's water for subsistence in San Antonio.

In 1843 French and German immigrants began arriving in San Antonio. Soon problems arose between the immigrants and the townspeople concerning land ownership and water rights. As a result, the city council was moved to translate all laws regarding acequias and their operation from Spanish and English into German and French. These translations were to be placed in public places by 1844 (Broussard 1967:33). The unfamiliarity with the laws and customs that governed the acequias caused great alarm in the city council. On May 15, 1847, the council used its power to insure a water supply for its own use by setting aside every fifth day for city use (City Council Minutes, Journal A, 1847).

The German and American populations grew, spreading their influence throughout the city and consequently much of the architecture and the municipal government took on an Anglo flavor. The first American ditch commissioner was Capt. J. $H$. Beck, appointed in 1850 (Corner 1890:50). In 1852 the state legislature placed the construction and operation of irrigation works owned jointly by two or more different persons under the control of the county courts. The courts were authorized to order meetings for election of commissioners and to assess and collect fines (Hutchins 1928:269). On August 17, 1852 a committee was appointed by the court to draft rules and regulations for civil and police administration of irrigation property in Bexar County (Commissioners Court Minutes, Vol. A-1:81). It is interesting to note that the charter provisions made both at this time and later reflected Spanish control methods for irrigation.

Holmes (1962:83) contends that the acequias were permitted to fall into a state of disrepair due to a cycle of wet weather starting in 1855. At this time a traveler through Texas noted:

The system of aqueducts for artificial irrigation extends for many miles around San Antonio... . These watercourses still retain their old Spanish name "Acequia." 
A large part of them are abandoned but in the immediate neighborhood of the city they are still in use, so that every garden patch may be flowed at will (Holmes 1962:83).

In 1856 the corporate bounds of the city of San Antonio extended six miles from the San Fernando Cathedral (Huesinger 1951:26). The expansion of the city created problems with the acequias. Among the problems were those concerning all road or pedestrian bridges crossing over the acequias. Holmes (1962:94) gives the accounts of city newspapers concerning this public problem; it is also well documented throughout the city council minutes. The city charter of 1857 empowered the mayor and the city council to reopen the old irrigation ditches, within or beyond the city limits of that time, and to regulate all matters pertaining to the operation and the distribution of water for irrigation. The charter also made it an offense, punishable by fine or imprisonment, to defile the San Pedro Ditch by washing clothes, watering horses, or any other means.

In 1859 the U.S. Army acquired a Targe section of land, south of downtown San Antonio, for an arsenal (Huesinger 1951:27). The San Pedro Ditch ran through the property and was still in operation at the time the arsenal was built (Fox 1978a:3).

The 1860s brought 1ittle change to the San Antonio acequia system. The war between the states brought confusion and problems to the controlling authorities, and the economy of San Antonio was at a low ebb. Ramsdel1 (1959:45) quotes Vinton James:

The trash and garbage was thrown into the backyards.

Drinking water was obtained from shallow wells and

irrigation ditches, and this water became contaminated

from outhouses, and typhoid fever and malaria were prevalent.

In 1866 a cholera epidemic broke out in San Antonio, which was probably the incentive the city needed to force a cleanup.

In the 1870s prosperity once again came to San Antonio. The ranches brought capital to San Antonio as a result of the high prices paid for wool and cattle. The railroad came through in 1877 and boosted the prosperity even higher. The San Antonio Water Company was organized the same year; it drew its water from the headwaters of the San Antonio River (Corner 1890:55). The neglected acequias began to be refurbished, and the city council passed a resolution in 1879 to clean the acequias:

. . . sum of $\$ 690.00$ or as much as to be necessary to clean San Pedro, Upper Labor, and Alazan in accordance to city charter (City Council Minutes, Vo1. E, December $5,1879)$.

To keep the acequias clean, an ordinance against defiling the water in the ditches was passed November 16, 1880 (City Council Minutes, Vol. E, 1880).

The 1880s brought a revival in caretaking and usage control of the acequias. It appears that any subsequent changes made to the acequias were to be approved by the city council. On April 18, 1882 the city council approved a 
measure to put a cover over the San Pedro Acequia from Story's Stable to Houston Street, and Houston Street to Simon Fest's property. On February 21, 1882 the city council was petitioned to straighten the ditch that ran through the U.S. Arsenal and to build a bridge over the acequia at Arsenal Street. On April 17, 1883 a proposal to stone 1 ine San Pedro Ditch through San Pedro Park, a distance of 300 to 400 feet, was brought before the counci1. A short time after completion, a public improvement project was initiated to raise the park's acequia west wall 12 more inches for the entire length of the wal1. As late as 1887 the citizens petitioned the city council for protection from overflow of the acequia. On September 19, 1883 an estimation of $\$ 200.00$ was made for 200 yards of erected stone wall at the place of the overflow.

The drilling of artesian wells, as well as the founding of the San Antonio Water Company, helped eliminate the need of the acequia for a clean water supply. The drilling of the wells into the lower rock stratum was said to have a diminishing effect on the water issuing from the springs (James 1938:149). Since the San Pedro Acequia took its water from such springs, it was soon to become an unreliable source of clean water. The acequias of San Antonio then began to take on a new role, that of collecting run-off water. Arneson (1921: 129) writes:

Sma11 watercourses, carrying storm waters, were frequently allowed to empty directly into the canal. When this was done, however, a masonry wall or wasteway, was provided in the lower bank of sufficient size to permit al.1 the storm water to spill over at that point, thereby not endangering the canal with wholesale washouts.

Holmes (1962:117) also quotes Andrew Morrison on the subject of a need for a more modern drainage system for the increased population. The population in San Antonio was 12,256 in 1870 and increased to 37,673 in 1890 (Ramsde11 1959: 60). The city streets were being improved by macadamizing or surfacing with mesquite blocks. These improvements, along with building constructions, virtually eliminated the natural ground where water could be absorbed, thus creating a larger amount of run-off water during wet weather.

The acequias soon became less important. Petitions began to filter into the city council meetings for closing portions of the acequias. Pros and cons were heard by the council; reports by physicians and engineers were heard, and the evidence was weighed. Despite the increasingly negative attitude toward the acequias, it was the general concensus of the city council to keep the channels open and to continue improvements wherever needed. In 1891 a resolution was passed to build storm and trash gates on the San Pedro Acequia 200 yards north of $W$. Houston Street.

Trash and stagnant water were always present in the acequia and the city was worried about this as a serious health problem. Mayor George Paschal reported to the city council in 1893:

- . fifty tons of filth pollutes the streams in San Antonio everyday (Lomax 1948:35). 
He also reported to the council the necessity for clean water, indicating that one in every 57 people dying yearly from unclean water in San Antonio was cause for concern. Perhaps this was the beginning of the end for the acequias running through the city. The city government abolished the ditch commissioner's office in 1899. It was not until 1906 that the water is said to have ceased flowing in the San Pedro Acequia (Schuchard 1951:30). Six years 1ater, on September 3, 1912, an ordinance was passed to have the San Pedro Acequia officially closed (City Council Minutes, Vol. V., September 3, 1912).

\section{PREVIOUS ARCHAEOLOGICAL RESEARCH}

There are literally miles of acequias (water ditches) criss-crossing and latticing the metropolitan area of San Antonio and lands to the south (Fig. 1:Locations 1-11). There have been comparatively few detailed archaeological investigations and publications dealing with these facts of pioneer engineering.

The first series of excavations was made by the Texas Historical Survey Committee, in collaboration with the Witte Museum, at the Acequia Madre in Hemisfair Plaza (Location 1) and the Zilker property just north of the Downtowner Motel (Location 2). Both excavations revealed ditches 7 ined with walls of 1 imestone block (Sorrow 1972). In 1969 the Texas Archeological Salvage Project excavated part of the Acequia Madre (Location 3) just north of the Daughters of the Republic of Texas Library on the Alamo grounds (Sorrow 1972).

During 1973 to 1980, the CAR-UTSA conducted the following field investigations of the acequia system. In 1973, Thomas R. Hester excavated a small portion of the same acequia on the Alamo grounds (Location 4) just behind the souvenir shop (Adams and Hester 1973). In 1977 portions of the San Pedro Acequia on the old U.S. Arsenal property, just east of the commander's house (Location 6) were uncovered. This excavation revealed the acequia to have 1 imestone block walls (Fox 1978a). During the same year, portions of the Alazan acequia just southwest of San Pedro Springs Park were excavated (ibid.). Excavations under the field direction of Paul Katz uncovered what is believed to be an unlined acequia near Hemisfair Plaza (Location 8) in the Arciniega Street area (Katz 1978). In 1978 the Center conducted investigations at the Gresser House (Location 5), where an unlined ditch, perhaps a costador (lateral or branch) of the Conception Acequia was uncovered (Ivey 1978b). In 1979, the Center investigated the Alamo grounds along the north wall (Cavalry Courtyard), where an earthen ditch northwest of the museum was uncovered (Location 10); the identification of this ditch is still being considered (Fox and Ivey, report in preparation). In addition, field work has just been completed by the Center on the Alamo Plaza-River Walk Linkage project on the west side of Alamo Plaza. Here a branch of the Acequia Madre was uncovered (Location 9), and it was found to be unlined (Ivey and Fox, report in preparation).

\section{TEST TRENCH OBSERVATIONS}

Below are the descriptions of test trenches 1-13 which were dug under the supervision of Fred Valdez, during Phase I of the San Pedro Acequia investigations. 


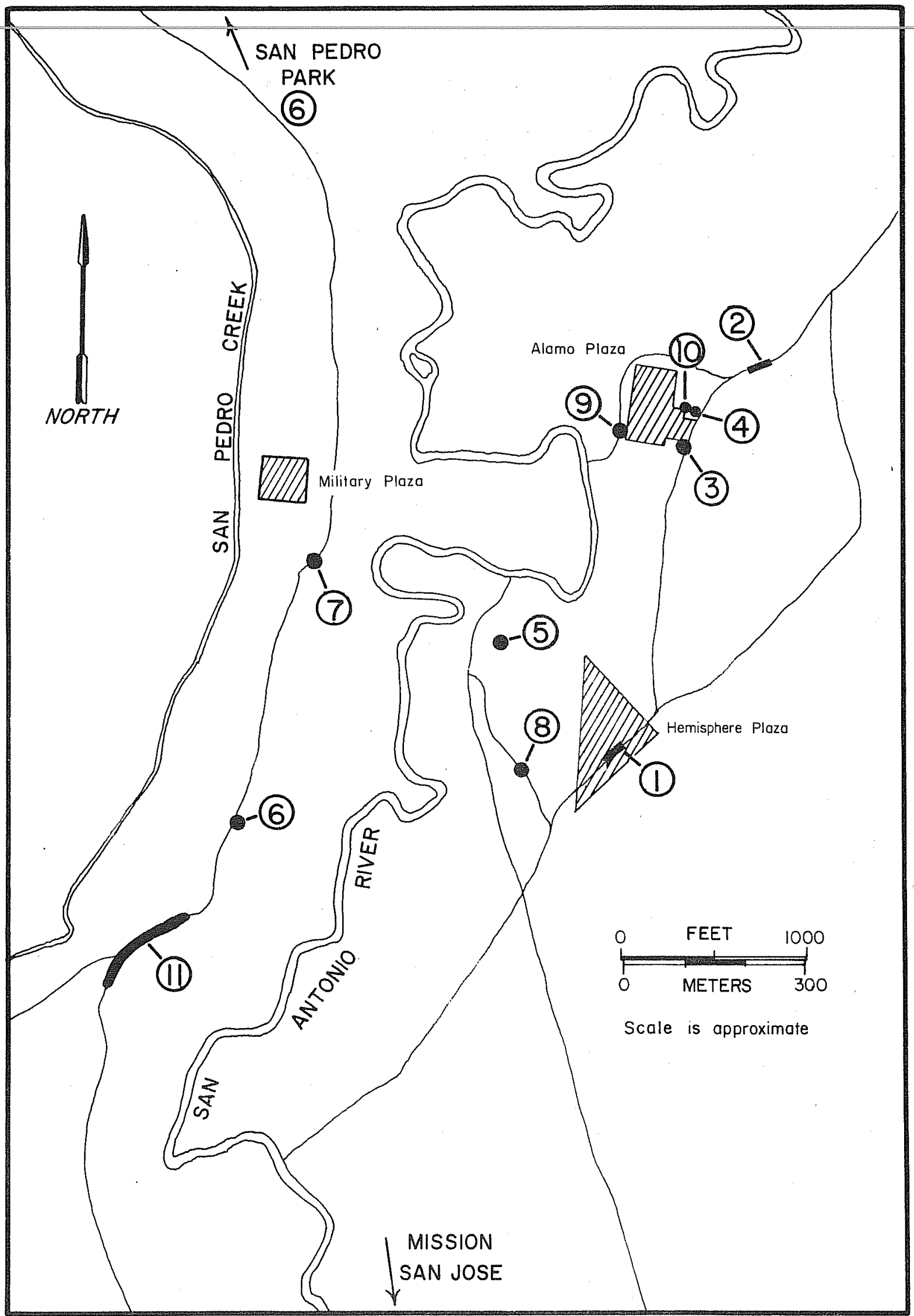

Figure 1. Map of the San Antonio Area Indicating the Locations of Previous Archaeological Investigations of Spanish Colonial Acequias. The circled numbers correlate with descriptions in the text. 
This will be followed by descriptions of test trenches $A-R$ which were dug under the supervision of Augustine Frkuska during Phase II of the investigations. Figure 2 indicates the locations of these trenches and the actual routing of the San Pedro Acequia through the GSA properties.

\section{Observation Phase I}

\section{Trench 1}

This trench was excavated parallel to $W$. Sheridan Street where the San Pedro Acequia was estimated to enter the GSA property from the north (Fig. 2). The trench, which began 96 feet west of the corner of Sheridan and S. Main, was about 98 feet in length and 40 inches in width. The soil stratigraphy of the south wa11 of the excavated trench indicated that the acequia was dug through 12 inches of black alluvium or loam followed by 24 inches of brown clayey loam. Below this was 19 inches of brown sandy loam which lay upon basal caliche.

The distinctive profile of a shallow ditch, beginning at the surface and extending 51 inches down to the caliche base, was noted (Fig. 3). The width of the ditch measured approximately 9 feet (the base of the ditch was at caliche bedrock as noted). The fill consisted of two major levels. The earliest deposit was a clayey ash and charcoal loam approximately 23 inches in depth. On the east side of the ditch (acequia) was a vertical wooden post. This post is possibly a remnant of a retaining wall structure built to slow the erosion on the east bank. The second major deposit was approximately 29 inches in depth and consisted of a silt fill with charcoal flecks. It was within this second layer that the majority of artifacts were found.

\section{Trench 2}

This trench was located about 25 feet from W. Johnson Street (Fig. 2). The trench was dug parallel with the street to a length of 98 feet and a depth of 2 feet. The trench profile revealed 16 inches of black topsoil covering 12 inches of a dark brown clayey loam. Below this was 8 inches of brown sandy loam which rested upon basal caliche. No ditch profile was noted in the trench walls.

\section{Trench 3}

This trench was located 31 feet south of Trench 1 (Fig. 2). The trench was dug to a length of 28 feet and a depth of 45 inches. A profile of a ditch was noted and recorded in the south wall of this trench (Fig. 3). The trench was cut through the same stratigraphy as noted in Trench 1. However, the widths of the deposits varied in this southern wall profile.

The ditch profile appears to represent a disturbance in the acequia's east bank. A small pipe was placed parallel to the ditch, probably utilizing the previously excavated acequia when it was open. The present ditch measures a1most 13 feet in width and 38 inches in depth. However, the actual width of San Pedro Acequia would be closer to 10 feet. The oblique angle in which the 


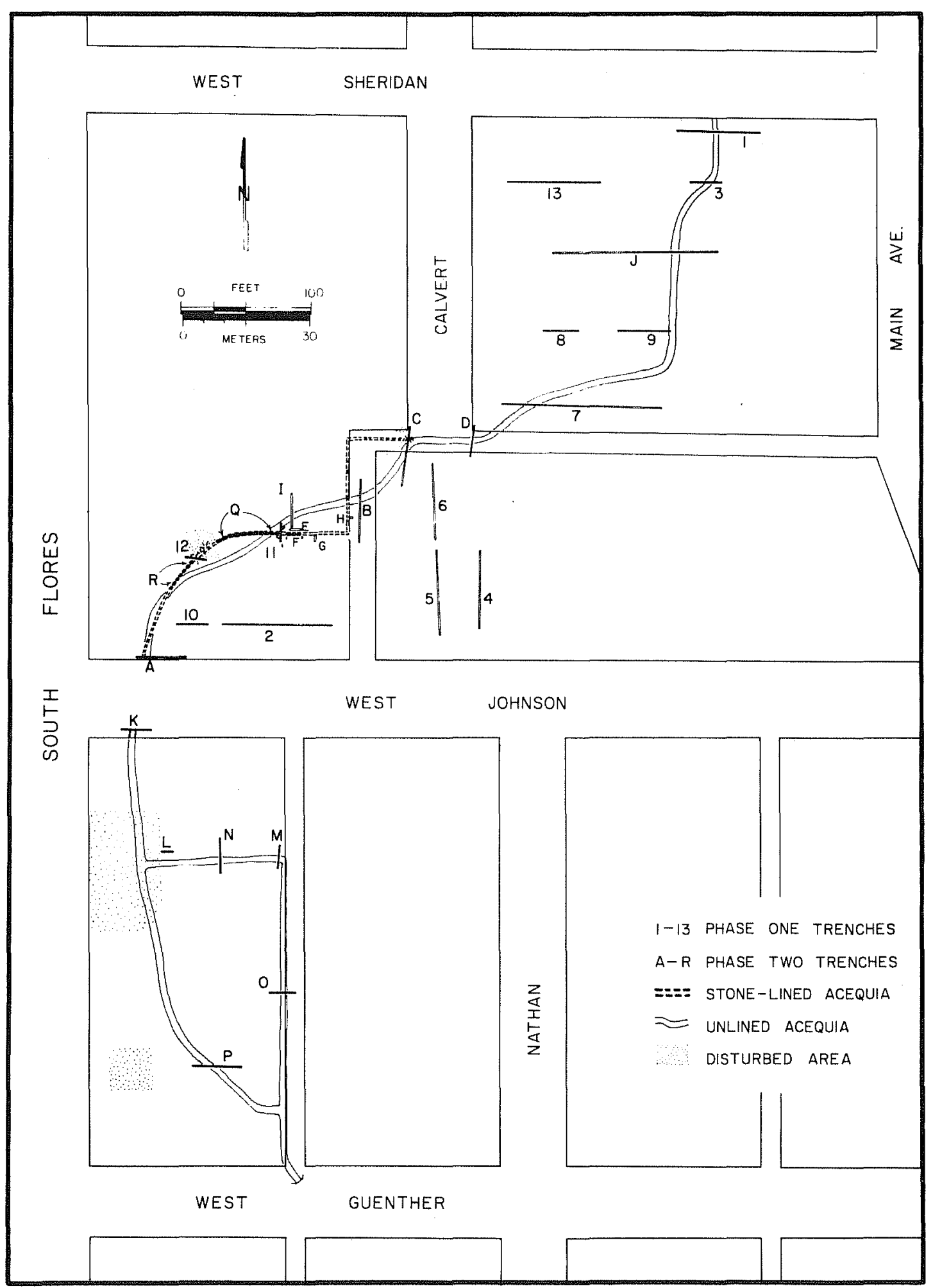

Figure 2. Plan of General Services Administration Property Indicating the Locations of Test Trenches and the Routing of the San Pedro Acequia. 
trench was cut gives an appearance of a wide acequia channel. The acequia fill consisted of four major deposits. The earliest deposit was 12 inches of an ash and charcoal lens containing very few artifacts. A dark silt deposit 10 to 24 inches in thickness rested upon the ash and charcoal lens. Cultural debris was also noted in this layer. The latest deposit is approximately 10 inches thick and consists of mixed topsoil.

\section{Trenches 4,5 , and 6}

These three trenches were placed north of $W$. Johnson Street running parallel to the Calvert Street extension shown in Figure 2. Each trench measured 72 feet in length. Trench 4 lay to the east of Trench 5. Trench 5 and Trench 6 ran north and south along a common line. Soil profiles revealed natural stratigraphy with some surface modifications. The first 8-12 inches of surface material contained gravel and brick fragments mixed with soil. Below this was 8-12 inches of dark clay, 16 inches of dark brown clay, and 8 inches of light brown soil with caliche mixed in. This rested upon basal caliche.

\section{Trench 7}

This trench began $10 \mathrm{~m}$ east of Calvert Street and approximately 220 feet south of W. Sheridan (Fig. 2). The trench was dug west to east for a length of 148 feet. The north wall of the trench displayed a profile of a ditch 9 feet in width and 29 inches in depth (Fig. 3). The ditch had been dug through 8 inches of alluvial topsoil followed by approximately 24 inches of dark brown clay loam. Below lay 12 inches of yellowish tan clay loam which covered basal caliche.

The ditch profile displayed three major layers of deposits. The bottom layer consisted of a 5-inch charcoal lens with a silt mixed in. Upon this rested a 6 -inch burned ash lens with cultural debris. The top deposit consisted of a gray silt with cultural debris 16 inches thick at its widest point.

\section{Trenches 8 and 9}

These two trenches were located north of Trench 7 and parallel with W. Sheridan (Fig. 2). The profiles revealed the basic natural soil stratigraphy as described in previous trench profiles. Trench 8 was dug to a length of 25 feet and Trench 9 to a length of 50 feet. No acequia outline was noted in either of the trenches.

\section{Trench 10}

This trench was placed west of Trench 2 and parallel with w. Sheridan (Fig. 2). The west end of the trench was located 65 feet from S. Flores Street. The purpose was to extend the testing in that area to expose the acequia.

The soil stratigraphy differs from what was found in Trench 7 . In the eastern part of the trench the topsoil was a gray-brown clay about 43 inches in depth. Below this was 16 inches of brown clay loam which graded into caliche gravels. The west side of the trench displayed dark brown topsoil overlying large grain sand to caliche bedrock. No sign of an acequia was found in this trench. However, the evidence of disturbance in the area is obvious. 
Trench 11

This trench was located 33 feet north of Trench 2 and 145 feet east of S. Flores Street (Fig. 2). The trench was dug south to north for a length of 15 feet. The trench exposed two parallel walls of cut limestone block running east and west.

The walls of the acequia are 20-22 inches in thickness and spaced 35 inches apart (Fig. 3). The walls are vertical and measure 39 inches from the top to the unlined bottom. The limestone blocks appear to be faced with a pink colored sandy lime mortar. Chinking was used to fill spaces and to help set the stone upon the caliche bedrock.

The interior fill of the acequia is represented by two deposits. The first is a 6-inch layer of dark gray clay containing charcoal flecks and a few cultural artifacts. The remaining fill is a caliche and soil mix with an abundant amount of cultural debris. It would appear that this fill was intentionally deposited to fill the acequia. On top of the acequia is an 8-inch layer of asphalt. This asphalt covered any surface indications of the stone-lined acequia below.

\section{Trench 12}

This trench was located 58 feet west of Trench 11 and 80 feet north of W. Johnson Street (Fig. 2). The trench was dug east to west to a length of 10 feet. The trench was placed at this location to expose the acequia which appeared to turn in a southerly direction as indicated by surface anomalies. A portion of the 7 imestone block wall was uncovered. The direction of the acequia appeared to angle toward the corner of $S$. Flores Street and W. Johnson Street.

The south wall of the trench revealed the stone-lined acequia as described in Trench 11 (Fig. 3). However, the stone walls at this location were covered with 8 inches of dark topsoil, and there were three layers of deposits within the acequia walls. The bottom layer was 12 inches of dark gray clay of the same description as found in Trench 11 . Upon the gray clay lies a 5-inch layer of sandy silt with snail shells throughout the level. The remaining 22 inches of fill was a caliche soil mix containing the majority of the cultural material collected. The acequia at this location did not rest upon the caliche bedrock.

\section{Trench 13}

This trench was dug east to west. The west end of the trench was 26 feet east of Calvert Street and 46 feet south of $W$. Sheridan Street. The length of the trench was approximately 73 feet. The purpose of the trench was to see if the stone-1ined acequia was in the area, as suggested by its existence in Trenches 11 and 12. However, no acequia, lined or unlined, was found in the area. Soil deposition in the trench profile consisted of four distinct layers. The topsoil was approximately 16 inches of black alluvial loam followed by 12 inches of dark brown clay. Below this was 8 inches of brown sandy loam mixed with the caliche from the caliche layer below. 
TRENCH I

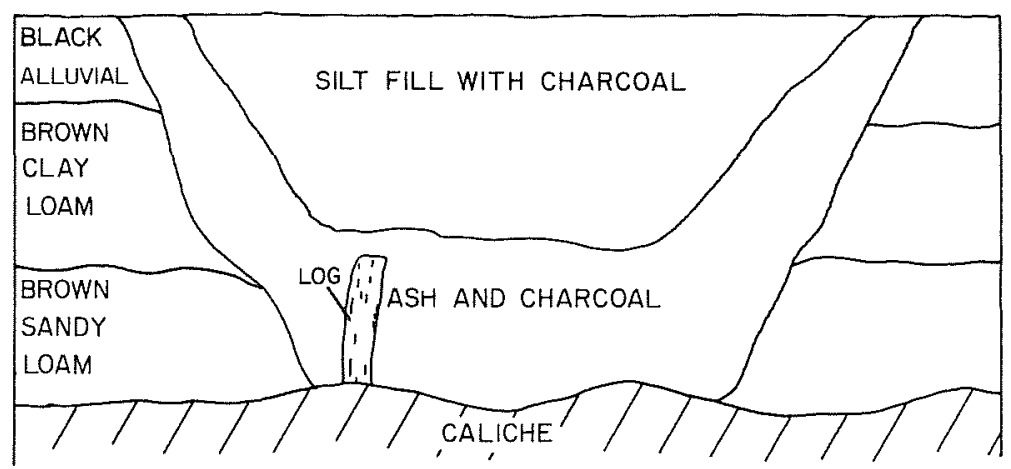

TRENCH 3

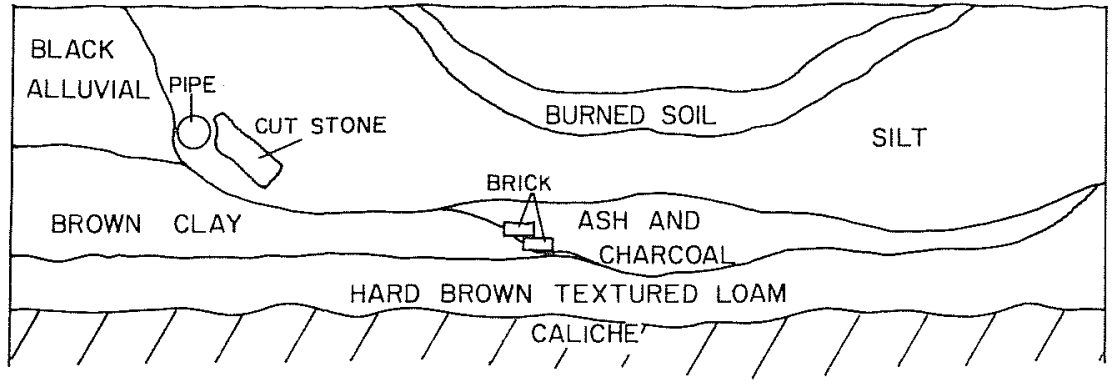

TRENCH 7

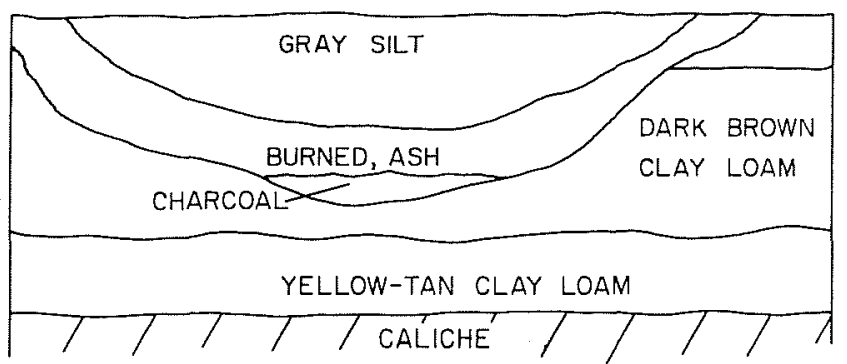

TRENCH II

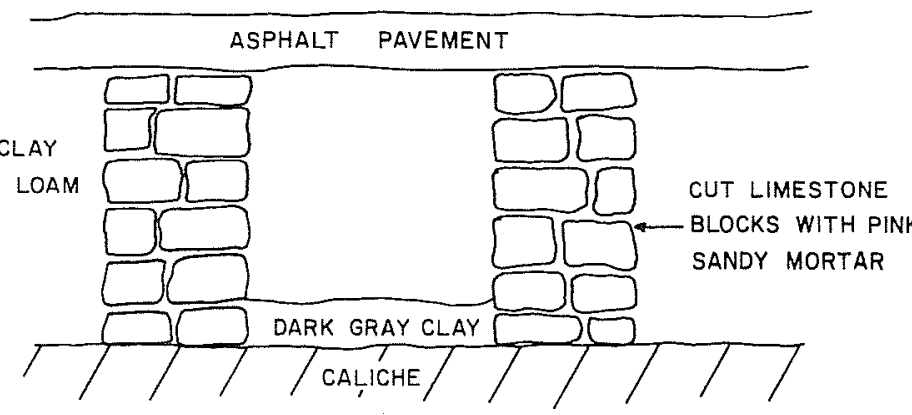

TRENCH 12

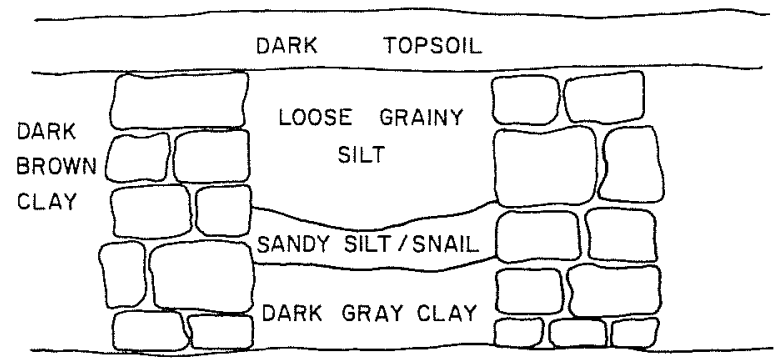

BROWN CLAY LOAM

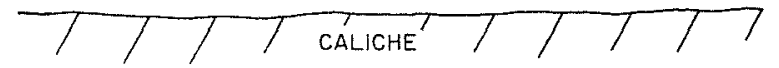

$41 \mathrm{~B} \times 337$

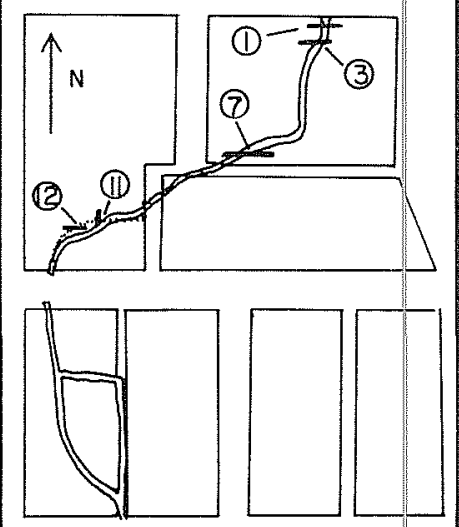

Figure 3. Soil Profiles Showing the San Pedro Acequia from Phase I. (After Valdez and Eaton 1979.) 


\section{Observation Phase II}

\section{Trench A}

Trench $A$ was positioned on the north side of $W$. Johnson Street just inside the sidewalk (Fig. 2). The trench was approximately 12 feet in length and 45 feet from the corner of S. Flores. The stone-lined acequia was encountered when the backhoe grazed the top of the limestone blocks. Excavation was continued by hand uncovering two parallel limestone blocks approximately 3 feet apart running in a north-south direction. The south end of the acequia continued beneath $W$. Johnson Street in which an iron pipe about 20 inches in diameter carried the water beneath the road surface. The limestone blocks were 1 foot below the present surface. They averaged 18 inches in width and the faces of the blocks contained chisel marks. The interior fill of the acequia contained caliche gravels and caliche soil mixed. No cultural artifacts were observed in Trench $A$.

\section{Trench B}

Trench B was placed on an improved extension of Calvert Street. The trench was oriented north and south, in anticipation of the acequia's path between Trenches 7 and 11 (Fig. 2). The south end of Trench B was begun 95 feet from W. Johnson Street and excavated to a length of 48 feet. The trench was dug to a depth that revealed natural caliche. Both walls of the backhoe trench were cleaned to observe the characteristics of the acequia (Fig. 4). The acequia is approximately 8 feet in width with a depth of 3 feet. A cedar post was noted on the north half of the profile, and a cedar plank was noted on the south half of the profile. The cedar post and board suggested the past construction of a retaining wall along both banks of the acequia.

The acequia appears to have been dug through two layers of natural occurring soils. The top layer is 24 inches thick and grades from a black to a dark brown clay loam. This is overlying a lighter brown clay loam about 12 inches thick. As noted in the earlier trenches of Phase I, the thicknesses vary due to the gradation of the soils. The brown clayey loam overlies a white caliche layer on which the acequia bottom also rests. The interior of the acequia is surfaced by a caliche fill with limestone chips associated with the gravel road. Beneath this layer lies what appears to be intentional fill of yellow-brown gravels, with a maximum thickness of 18 inches. Beneath this layer was a dark clay loam with numerous pieces of charcoal and cultural materials. The maximum thickness of this cultural layer was about 12 inches. The deposit that lies beneath the cultural zone consisted of a silty clay loam with gravels. No cultural debris was noted in this level.

\section{Trench $\mathrm{C}$}

Trench C was located approximately 18 feet from Trench B (Fig. 2). The southernmost point of Trench $C$ is 145 feet north of $W$. Johnson Street. The trench was oriented north and south with a total length of 45 feet. The west wal1 profile was cleaned and recorded (Fig. 5). The acequia in the profile was approximately 30 feet wide; however, this large width was due to the oblique angle in which the trench was excavated into the acequia's path. At the north end of the 


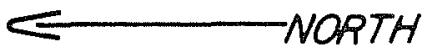

\section{TRENCH B}

EAST WALL PROFILE

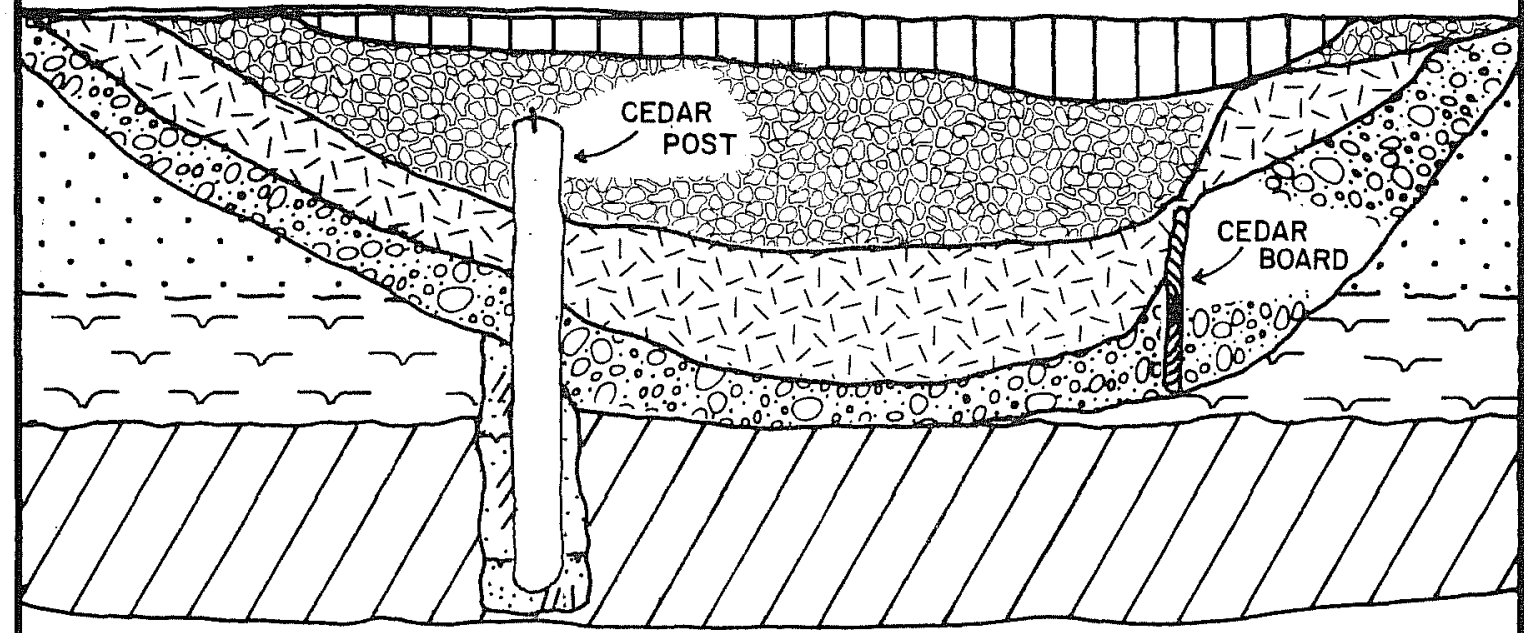

YELLOW-BROWN GRAVELS

BLACK SOILS WITH CHARCOAL

DARK SOILS, GRAVEL MIX

BLACK CLAYEY LOAM

BROWN CLAYEY LOAM

$41 B \times 337$

CALICHE FILL

CALICHE
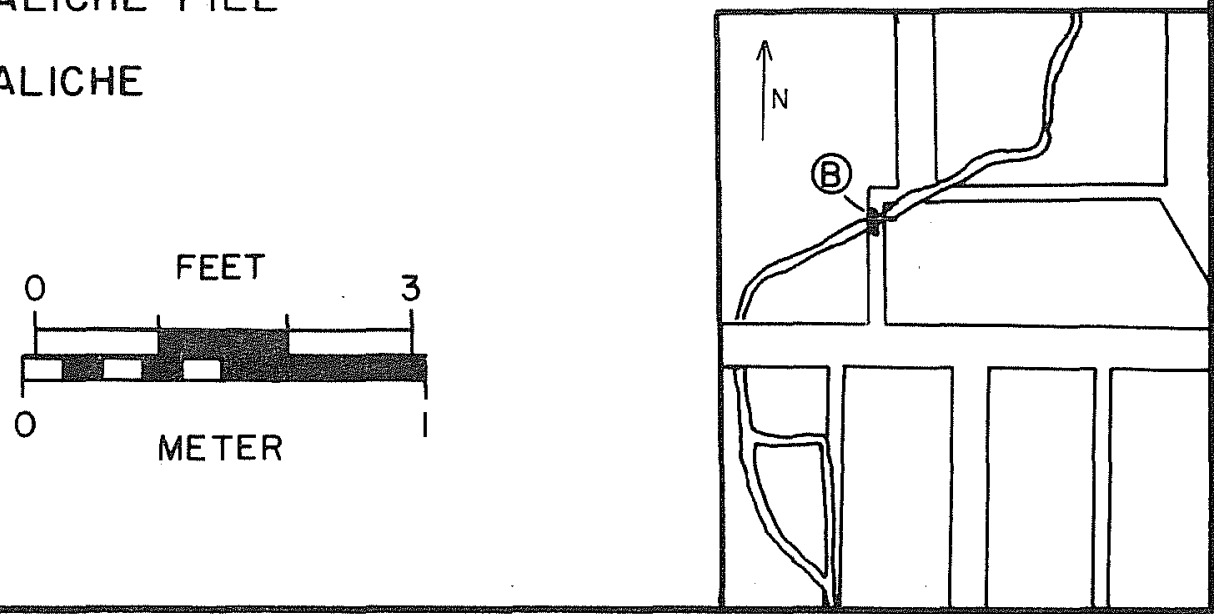

Figure 4. Soil Profile of Trench $B$. 


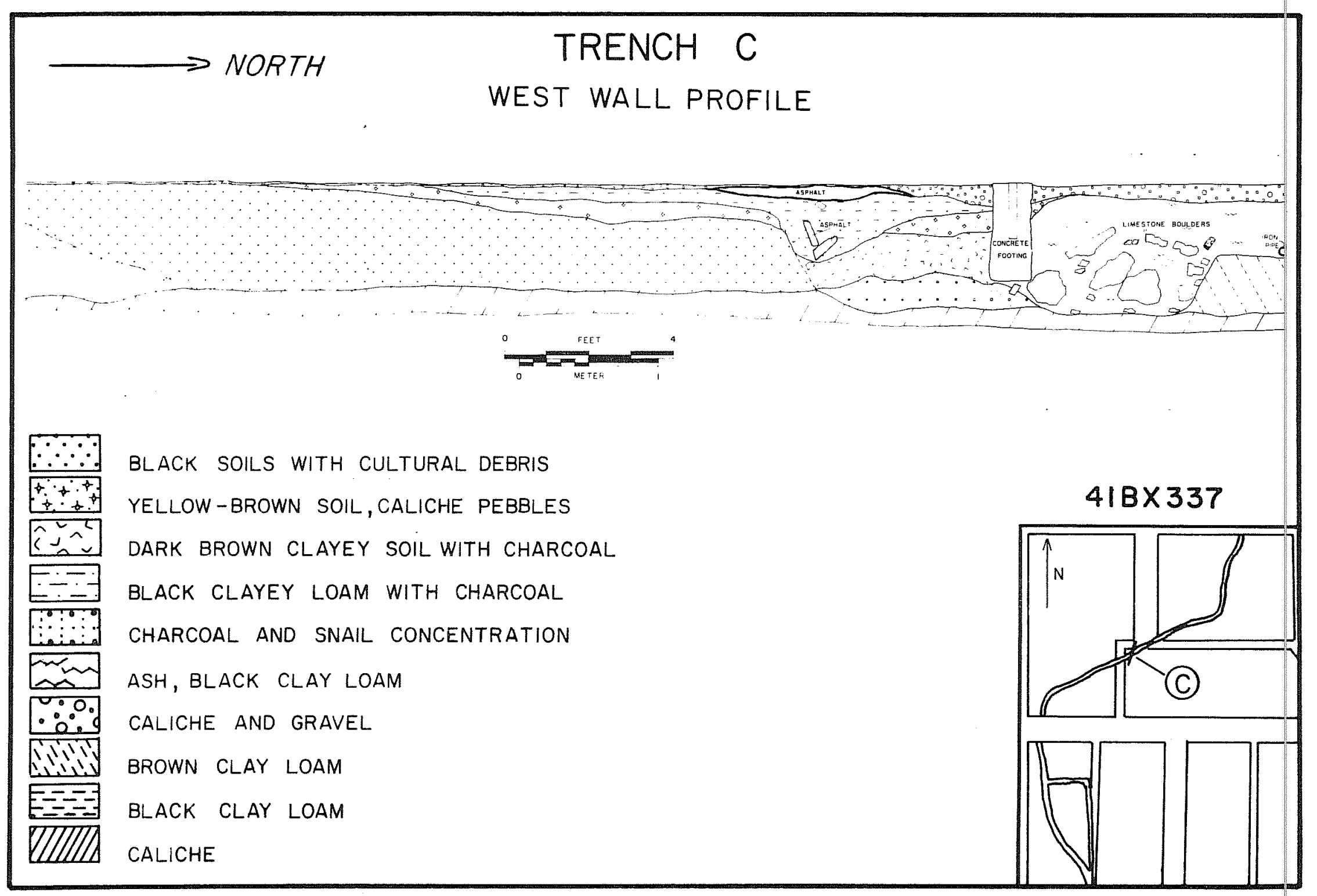

Figure 5. Soil Profile of Trench $c$. Note remains of 1 imestone block fragments. 
trench was a large amount of fractured limestone and a few pieces of these stones contained chisel marks on one face. This might suggest that in this area a junction was made of the stone-lined portion of the acequia and the originat unlined portion.

The acequia at this point was excavated through two clayey loam deposits. These loam deposits are described in Trench $B$ and represent the natural stratigraphy throughout the investigated area, unless otherwise mentioned. The acequia's interior fill consisted of caliche and limestone chips in the top layer. Beneath this layer in the northern portion is a black ashy clay loam with fragments of limestone block and other cultural materials. A large concrete pad superficially separated the two acequia sections. The unlined portion of the acequia underlies the road surface with 12 inches of black clayey soil containing chunks and pieces of asphalt. This layer overlies and intrudes into a yellow-brown soil with caliche gravels. This 6 -inch gravel layer rests upon a dark brown to black clay loam with charcoal pieces and some cultural artifacts. The oblique angle of the cut gives the appearance of a very thick layer containing cultural material. It is possible that the profile represents a thinner cultural layer that was deposited on the bank of the acequia. The bank was later excavated by the backhoe. Beneath this cultural zone was a layer of dark soils with a heavy concentration of charcoal pieces and land snail shells. No cultural materials were observed in this layer.

\section{Trench D}

Trench $D$ was located on the east side of Calvert Street approximately 50 feet east of Trench $C$. The southern end of Trench $D$ is approximately 160 feet north of $W$. Johnson Street. The trench was oriented north and south and was excavated to a depth of 3 feet and a length of 25 feet. The acequia had cut through two clay loam layers (Fig. 6), and the bottom layer rested upon the caliche bedrock. The width of the acequia measures 13 feet. Again, the angle of the trench cut made the profiled width wider than the actual ditch width. The interior stratigraphy contained ten distinct layers of fill. The surface layer was a reddish brown gravel occasionally topped with a thin lens of topsoil and grass. Beneath this initial layer was 12 inches of varying gravels. The gravel layers consisted of a yellowish brown gravel, a layer of black clay and gravel mix, and a similar layer of yellowish brown gravel. Beneath these gravel layers was a layer of dark soil with charcoal and snail shells. Within this 18-inch layer, household artifacts were recovered. Beneath this layer was a thin deposit of silt and rusted iron. The final two layers, or the first two depositional layers, are a black clay with caliche pebbles and a 3-inch layer of black silt with a heavy concentration of charcoal and land snail shells. The charcoal and shell concentration is a fairly common occurrence on the bottom of the acequia. A cedar plank found seems to divide two of the largest acequia deposits. The deposit on the north side was described above. The 12-inch deposit on the south side is a gray-black ashy soil. This layer rests upon the charcoal and snail she11 concentration level that runs continuous beneath the cedar plank. Across from the cedar plank, a post hole was encountered on the north bank of the acequia. The cedar plank with a distinct soil deposit on each side indicates that a retaining wall was in the acequia at this point. The post hole along with the plank suggests a structure contemporary with a similar feature located in Trench $B$. 


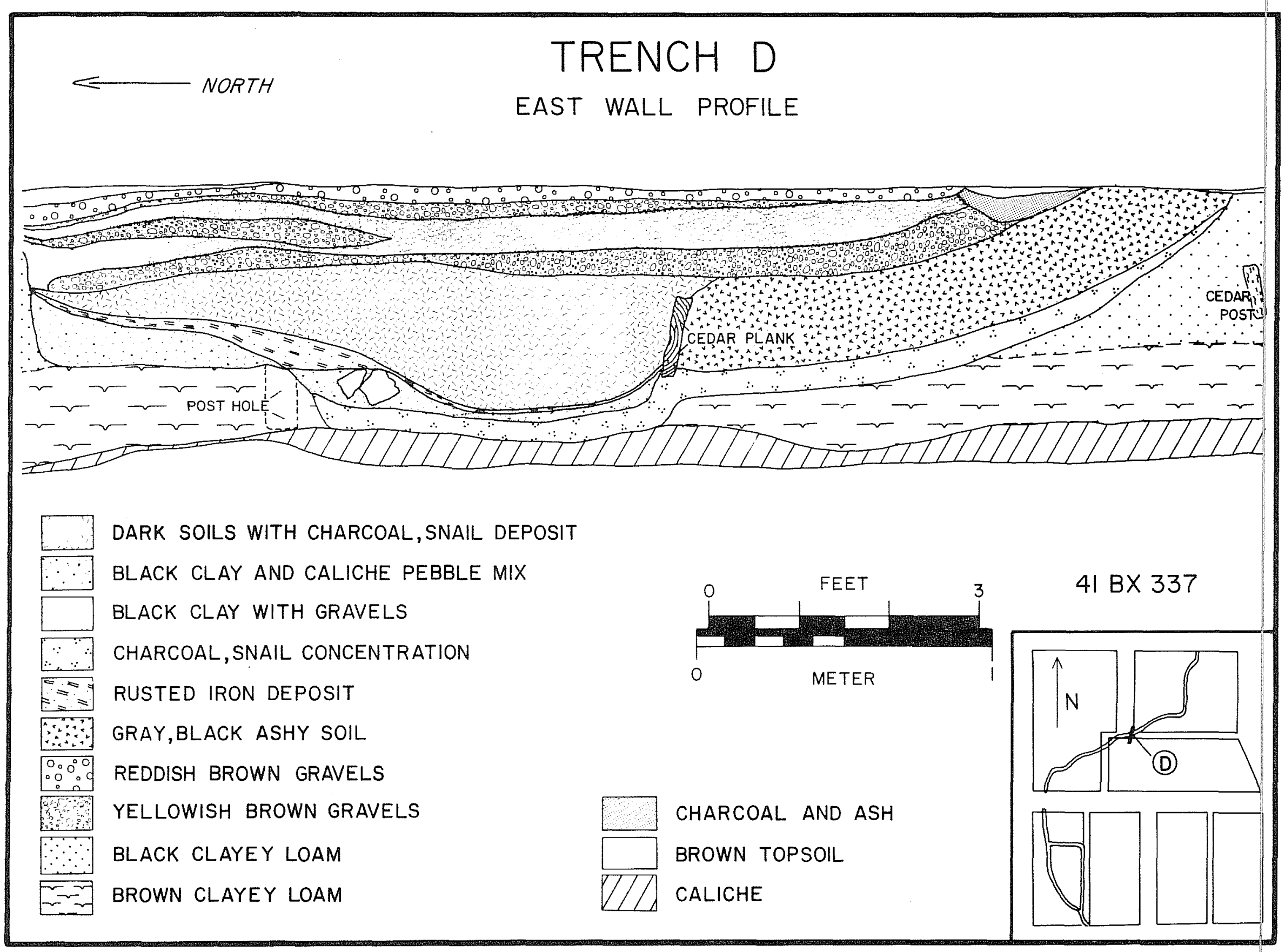

Figure 6. Soil Profile of Trench D. 


\section{Trench $E$}

Trench $E$ was excavated 10 feet east of Trench 11. The trench was placed on the outside edge of the north wall of the acequia (Fig. 2). The south wall of the backhoe trench was cleaned to expose the exterior block work of the acequia. The north wall of the backhoe trench was inspected for traces of the original unlined acequia. The unlined acequia route was projected from the profiles in Trenches B, $C$ and $D$ to intercept the stone-lined portion in this area. The exterior face of the acequia was roughly cut and unlike the dressed face of the interior. The north wall of the backhoe trench showed no sign of a ditch profile. The artifacts from this trench were found to occur along the outside fill of the stone-lined acequia.

\section{Trench $F$}

Trench $F$ was excavated inside the stone-lined acequia parallel with Trench $E$ (Fig. 2). The length of the trench measures 10 feet from Trench 11 to a concrete building foundation under which the acequia continues. Portions of the trench were excavated to basal caliche at approximately 3 feet in depth (Figs. $7,11, a)$. The interior face of the acequia was brushed clean and it was noted that the face was chiseled from top to bottom with a light brown sandy mortar between the blocks. The acequia interior fill was a homogeneous caliche soil with cultural artifacts. A thin layer of gray silt with a few snail shells and traces of charcoal 1 ie beneath. Noted within this caliche fill were large fragments of limestone slabs. These slabs suggested that the stone-lined acequia was covered at one time. The deposit suggests that the acequia was intentionally filled with caliche and debris.

\section{Trenches $G$ and $H$}

Trenches $G$ and $H$ were placed along the south and east perimeter of the concrete building foundation (Fig. 2). These trenches were approximately 2-1/2 to 3 feet in length. The objective was to verify the stone-lined acequia route, but the backhoe trenches east of Calvert Street showed no signs of the stone-lined acequia continuing in an east and west direction. Therefore, the stone-lined acequia route must continue north along the Calvert Street extension and make a $90^{\circ}$ turn to the east where it was observed in Trench $C$. No artifacts were recovered from the two short exploratory trenches.

\section{Trench I}

Trench I was located approximately 3 feet from the west end of Trench E (Fig. 2). The trench was oriented north and south with the southern end beginning on the north wall of the stone-lined acequia. The objective was to locate the unlined portion, but the negative results in Trench $E$ might indicate that the unlined portion is probably farther north. The trench was excavated to a length of 26 feet and a depth of 4-1/2 feet (Fig. 8). The center of the unlined acequia was found to be 15 feet 8 inches from the stone-lined portion. 
NORTH

\section{TRENCH $F$}

EAST WALL PROFILE

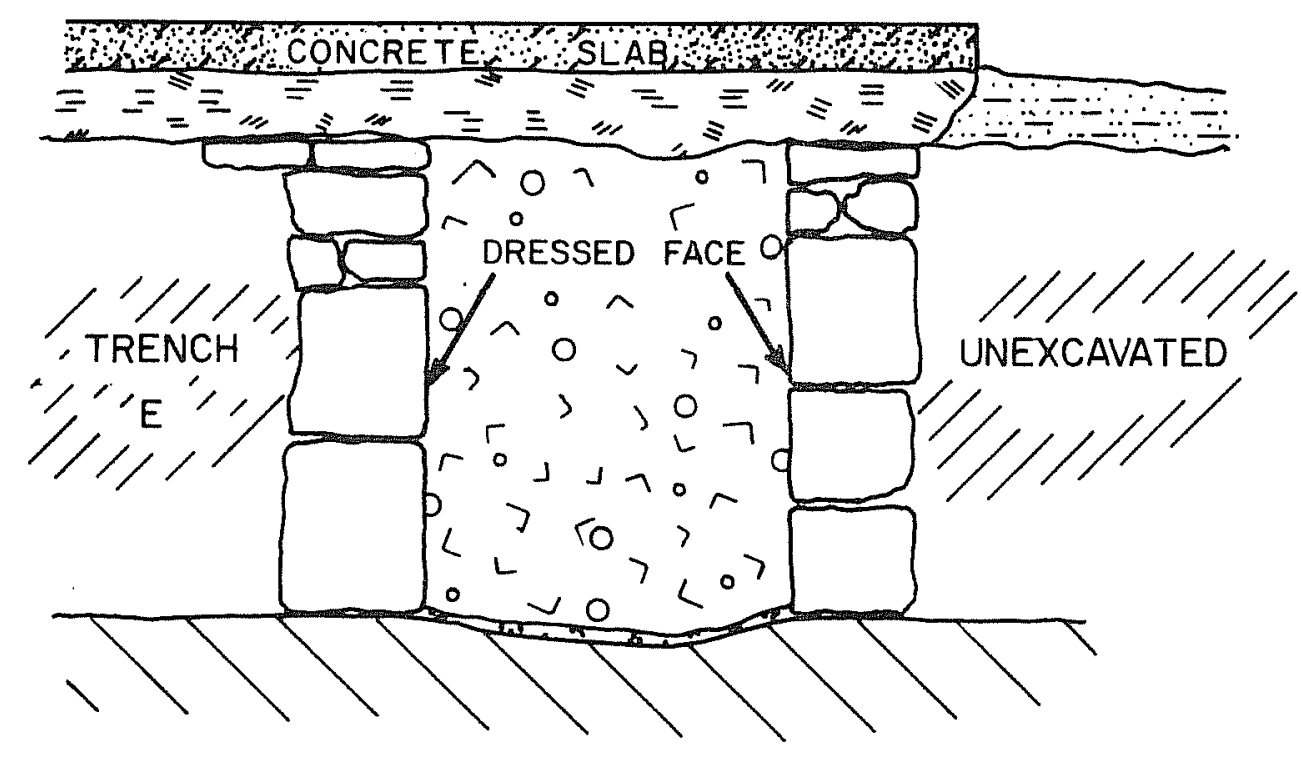

CDI CALICHE FILL WITH CULTURAL DEBRIS

FLAT (window) GLASS LAYER

$\because \because \because$ GRAY CLAY DEPOSIT

$\therefore \because$ DARK BROWN LOAM

$41 \mathrm{BX} 377$

MIIIV CALICHE
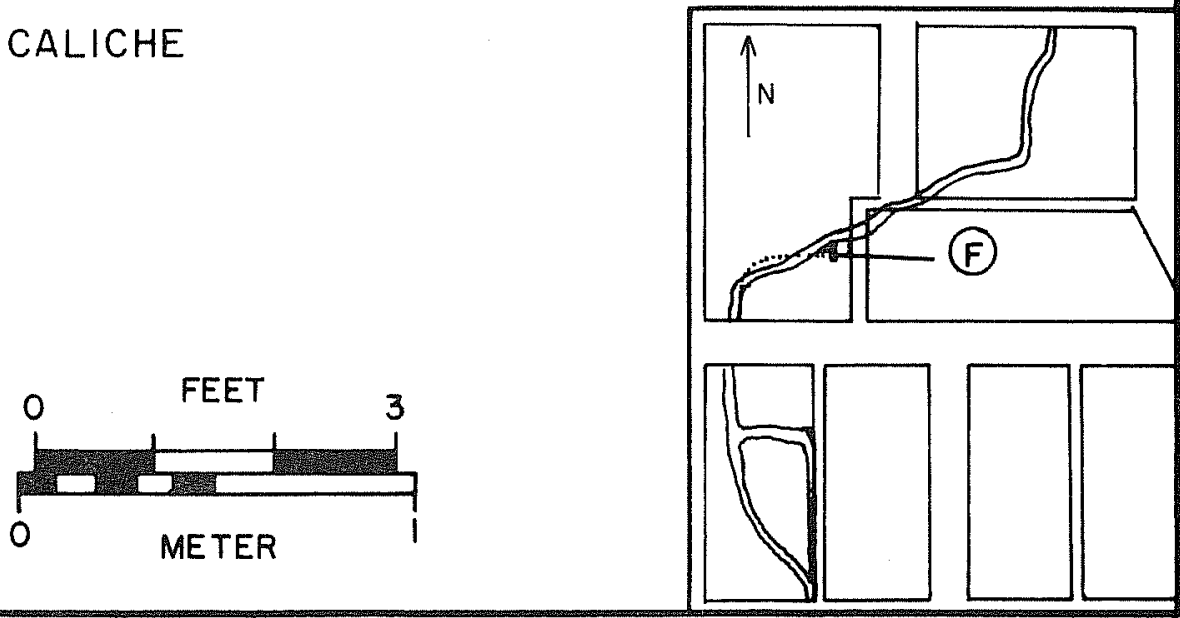

Figure 7. Soil Profile of Trench F Showing Masonry Work on Acequia. 


\section{TRENCH ।}

NORTH

WEST WALL PROFILE

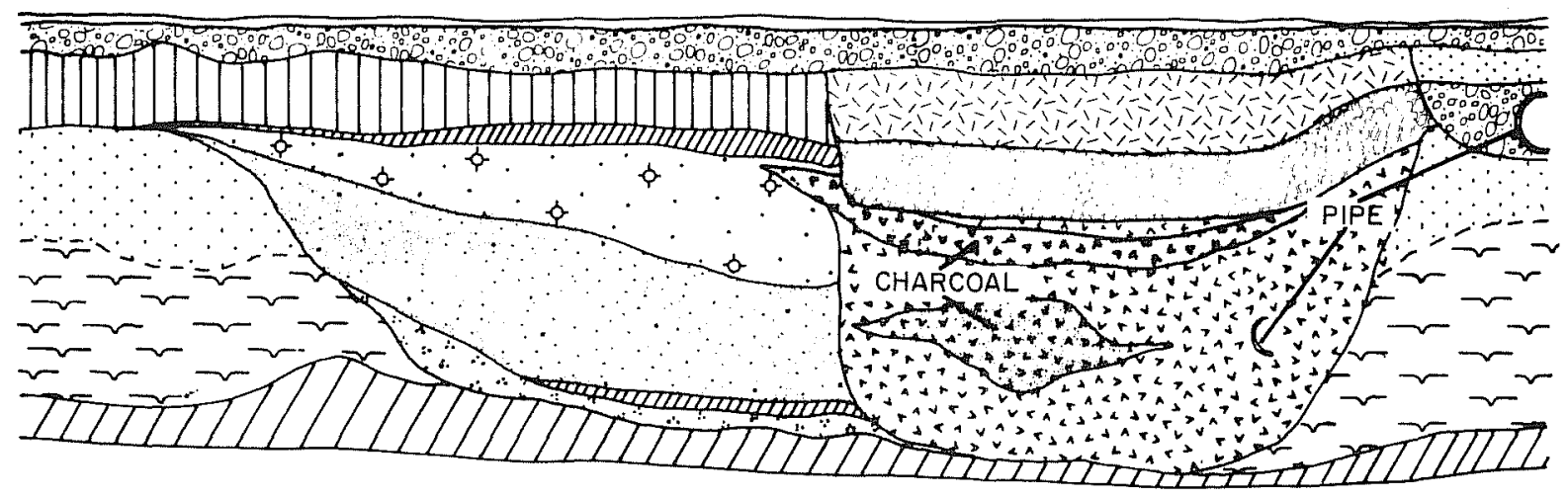

TRENCH J

$\lessdot$ EAST

SOUTH WALL PROFILE

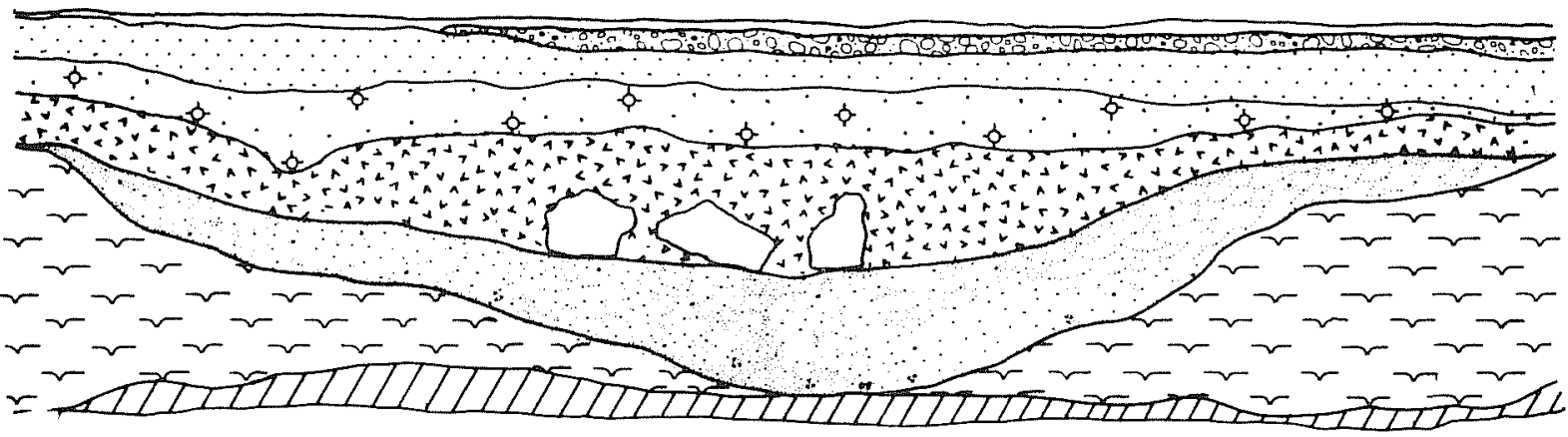

E蔔 BROWN SOIL WITH CULTURAL DEBRIS

FRAY CLAYEY SOIL WITH CHARCOAL

CHARCOAL, SNAIL CONCENTRATION

MOLDED GRAY, BROWN SOIL

GRAY, BLACK CLAYEY SOIL

IIIII YELLOW CALICHE FILL

BROWN CLAYEY LOAM

$\because$ BLACK CLAYEY LOAM

GRAVELS (PEA SIZE)

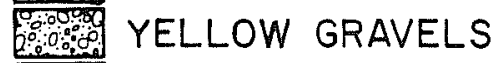

CALICHE FILL

CALICHE

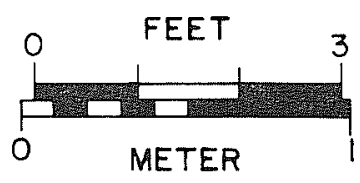

$418 \times 337$

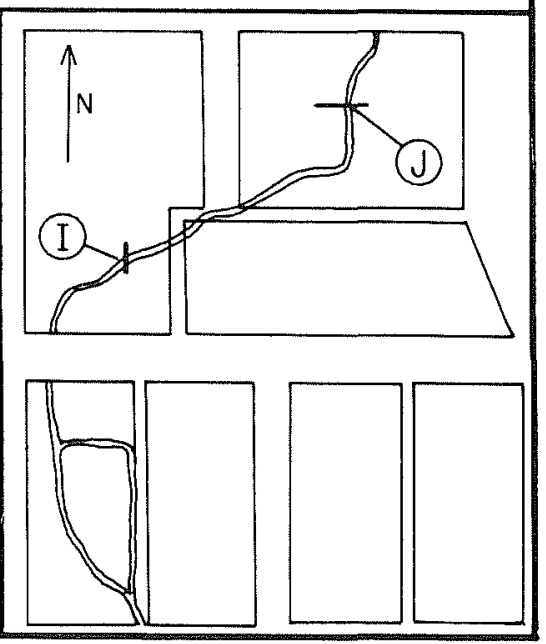

Figure 8. Soil profiles of Trench $I$ and Trench $J$. 
The profile of Trench I depicts two separate ditching operations within the original acequia. The acequia was dug through two natural clay loam levels and the bottom of the acequia rested upon the caliche bedrock. Above the acequia was a 6-8 inch layer of yellow caliche underneath a 4-6 inch layer of yellow gravels.

These layers were surfaced by a thin layer of asphalt and topsoil. The interior stratigraphy of the acequia consisted of five layers. The bottom layer was a thin deposit of silt with a concentration of charcoal and snail shells. Above the silt layer was a thin layer of caliche similar to the basal caliche. Rested upon the caliche layer was a 16-inch layer of a grayish brown soil. This layer contained few artifacts. Above the grayish brown soil was a 13-inch layer of gray-black clay soil void of any artifacts. Resting upon the clay was a thin layer of fine grain caliche similar to the basal caliche. Before this thin layer of caliche was placed upon the gray-black clay soil, a ditch approximately 30 inches deep was dug on the north bank of the acequia. The soil inside the ditch consisted of a gray clay with pockets of charred refuse and charcoal. Artifacts observed in this layer date from the middle twentieth century. Above this ditch a shallow trench 1-1/2 feet in depth was dug after the layer of yellow caliche was laid down. This shallow trench was filled with a 7-inch layer of pea-sized gravel topped with a layer of brown soil mixed with rubbish. The small drain uncovered just to the north suggests that the shallow trench was used as a lateral to disperse water underground.

\section{Trench I}

Trench $\mathrm{J}$ is an east-west backhoe trench. The trench was located between Trench 9 and Trench 3 (Fig. 2). The east end of the trench is approximately 120 feet west of Main Avenue, and 105 feet south of $W$. Sheridan Street. The trench was dug to a length of 123 feet and an average depth of 4 feet. The center of the acequia was located 33 feet from the east end of the trench (Fig. 8). The acequia was dug through two layers of clay loam ranging in color from a dark brown at the surface to a medium brown next to the basal caliche. The acequia measures an unusual 15 feet in width and approximately 30 inches deep. The unusual width is probably due to erosion of the banks and the angle of the trench cut.

The soil stratigraphy inside of the acequia consisted of three major layers of deposits. The bottom layer was a brown soil with a molded gray coloring mixed in. Fragments of land snail shells were noted close to the bottom of the level. A 15-inch gray clayey soil layer with pieces of charcoal rested upon the base deposit. The majority of the artifacts observed were collected from within this gray clay. Three large fragments of limestone containing chisel marks were also observed in this layer. Above this layer was a deposit of gray-black clay soil approximately 7 inches thick. This layer contained no cultural artifacts. Above this was a 4-inch layer of black clay loam, a thin layer of yellow gravels, and a surface layer of topsoil with grass.

\section{Trench $K$}

Trench $K$ was located on the south edge of $W$. Johnson Street and 25 feet east of S. Flores Street (Fig. 2). This trench was excavated to a length of 25 feet and a depth of approximately 10 inches. The probability of utility lines in the area 
determined the trench depth. A concrete cap was encountered 46 feet from S. Flores Street. The cap appeared to cover the stone-lined acequia and was poured into a wooden form approximately 3 feet wide. The length was not determined because of $W$. Johnson Street to the north and a sidewalk and building foundation to the south.

\section{Trench $L$}

Trench $L$ was designed to transect the acequia route east and west. The east end of Trench L was located 62 feet east of S. Flores Street and 86 feet from W. Johnson Street (Fig. 2). Trench $L$ was excavated to a length of 8 feet, terminating against a brick foundation and the foundation was found to continue 3 feet below the surface. The trench was located between two large concrete slabs. The materials unearthed included mortar and brick.

\section{Trench $M$}

Trench M was located east of Trench L approximately 82 feet south of W. Johnson Street and was parallel to a gravel alley (Fig. 2). The trench was excavated north to south for a distance of 20 feet, with a depth of 3 feet. The acequia's center was located approximately 98 feet south of $W$. Johnson. The acequia measured 8 feet in width and approximately 2 feet in depth (Fig. 9). The route of the acequia at this point ran east-west. The acequia was dug through two layers of clayey loam ranging in color from a black to a brown before the basal caliche was encountered. It appears that the natural soil layers observed north of $W$. Johnson Street holds true for the soils on the south side of W. Johnson Street.

There were three principal layers of deposition in the acequia. The primary deposit which rests upon basal caliche was composed of a silty loam a few inches thick with a concentration of charcoal and snail shel1s. Deposited on top of the bottom layer was 18 inches of dark soils intermixed with traces of charcoal and snail shells. It was within this layer that the majority of the cultural debris was observed. The final deposit consisted of three inches of caliche. A brown topsoil covers the area excavated by the trench.

\section{Trench $N$}

Trench $N$ was located between Trench $M$ and Trench $L$ in order to verify the acequia's location (Fig. 2). The trench was excavated to a length of 26 feet and a depth of approximately 4-1/2 feet. Unlike the previous trench, the acequia did not rest upon the caliche bedrock. It was, however, dug through the two familiar layers of clay loam. The acequia measured 10-1/2 feet in width and 24 inches in depth (Fig. 9).

The soils inside the acequia were made up of three major layers. The bottom and first layer measured 13 inches. This layer consisted of a dark soil intermixed with charcoal and snail shell. A gray ashy soil 10 inches thick rested upon the previous layer and together these first two layers held the few artifacts observed in this trench. The third layer consisted of a black clay. An 8-inch layer of yellow gravels and a thin layer of brown topsoil made up the 
$\leftarrow$ NORTH

TRENCH N

EAST WALL PROFILE

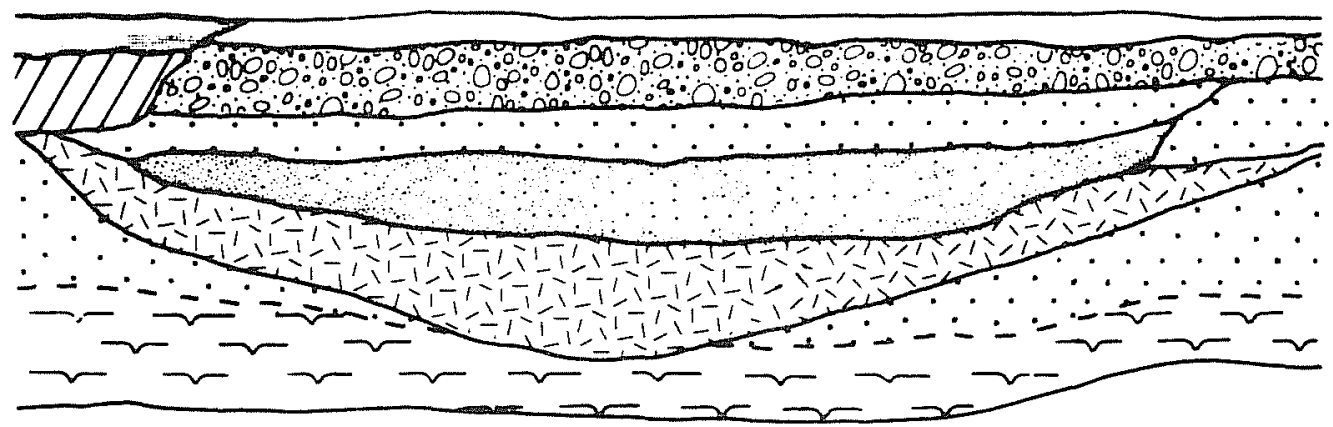

$\leftarrow$ NORTH

TRENCH M

EAST WALL PROFILE

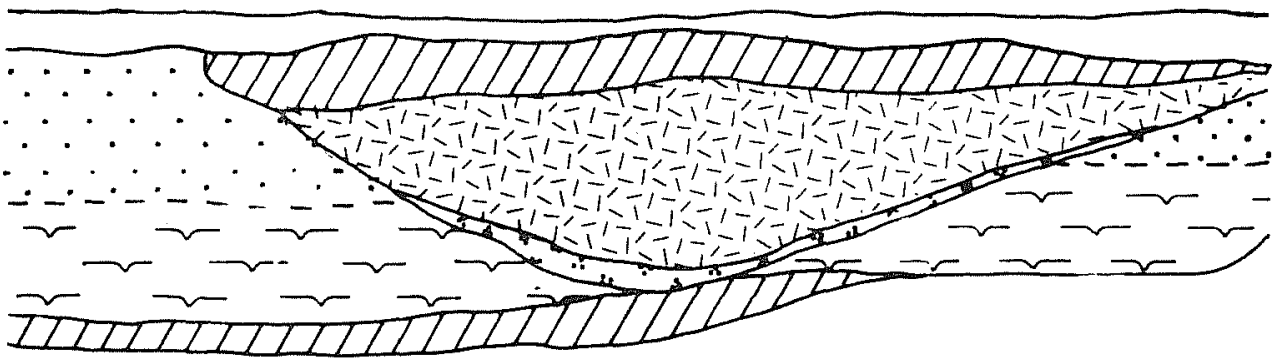

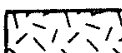
金证 $\because \because \because \because$

DARK SOILS WITH CHARCOAL, SNAIL DEPOSIT

CHARCOAL, SNAIL CONCENTRATION

RED BROWN SANDY SOIL

$\because \because \because$ BLACK CLAYEY LOAM

Eच

BROWN CLAYEY LOAM

GRAY ASHY SOIL

BROWN TOPSOIL

M0.0\%

YELLOW GRAVEL

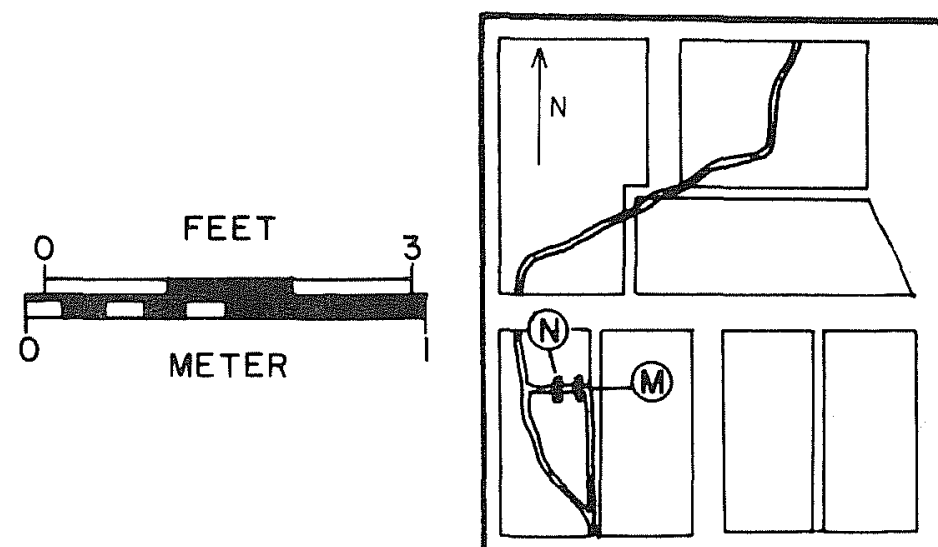

Figure 9. Soil Profiles of Trench $M$ and Trench $N$. 
remaining strata overlying the acequia. A shallow trench to the north was profiled, but no artifacts were observed.

\section{Trench 0}

Trench 0 was located south of Trench M (Fig. 2). This trench was located 196 feet south of $W$. Johnson Street and measured 20 feet in length and ca. 39 inches in depth. The profile of the acequia within the trench was 6-1/2 feet wide and 29 inches deep (Fig. 10). The acequia had been dug through the natural strata mentioned in Trench $M$; the bottom of the acequia rested upon caliche bedrock.

The interior fill of the acequia consisted of three deposits. The bottom deposit was a thin concentration of snail shells and charcoal mixed with dark brown clay. A very thin layer of rusted metal covered this bottom layer. A loose layer of black loam 26 inches thick rested upon the bottom layer. Within this loose fill there were cultural artifacts, limestone rock, and small pockets of caliche. A thin layer of yellow gravels rested over the cultural layer. Four inches of grayish black clay, another 4 inches of loose sandy soil and mortar, and a thin layer of topsoil with grass made up the remaining accumulations overlying the acequia.

\section{Trench $P$}

Trench $P$ was located southwest of Trench 0 (Fig. 2) and was excavated in a west to east direction. If Trenches $M, N$ and 0 represented a rerouting ditch, then Trench $\mathrm{P}$ should cut across the original acequia. The trench was excavated to a length of 38 feet and a depth of 70 inches. The acequia was uncovered on the east end of the trench and was located approximately 77 feet north of W. Guenther Street and 110 feet east of S. Flores Street. The acequia profile in the trench measures 18 feet in width and 23 inches in depth (Fig. 10). The obTique angle of the trench cut to the acequia route, and the badiy eroded banks caused the appearance of a large width. The acequia was cut through two layers of clay loam that rested upon a basal caliche. The description of the soils were detailed in earlier trenches.

The stratigraphy inside of the acequia represents five distinguished layers of deposition. The initial deposit that lies on the bottom was a thin layer of charcoal and snail shells. Above this layer was an 8-inch layer of dark soil containing cultural artifacts. The soil was a dark clay loam with a loose consistency, and small snail shell fragments could be seen within this level. Upon this layer were two caliche layers that measured a total of 3 inches. A grayto-black clayey soil level that measured 10 inches in depth and a 31-inch loose sandy soil level were the final two layers of soil accumulation over the acequia.

\section{Trench 2}

Trench $Q$ was located inside the stone-lined acequia between Trenches 11 and 12 (Fig. 2). The trench, which was about 56 feet in length, was excavated by hand to clear the overburden. The surface of the acequia's walls were cleaned and 


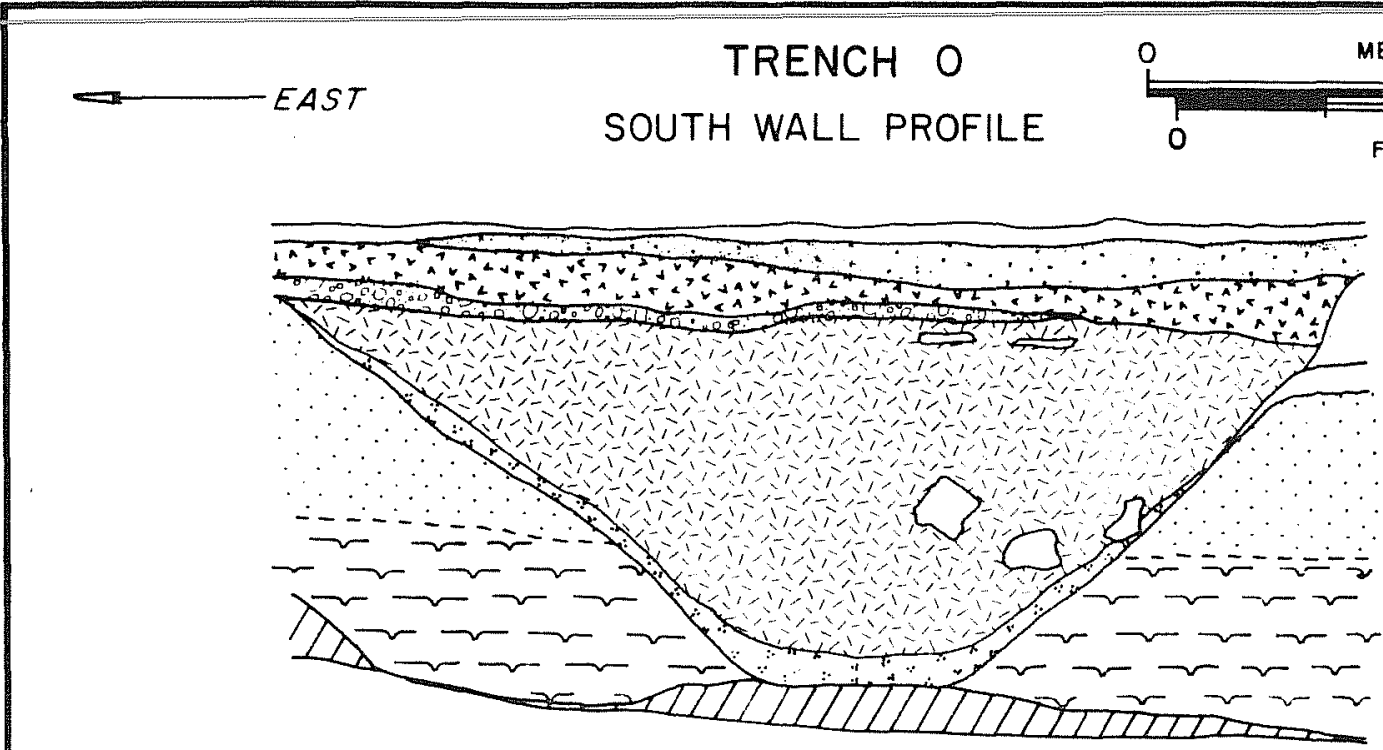

TRENCH P $\Longleftarrow-{ }^{-}$EAST SOUTH WALL PROFILE
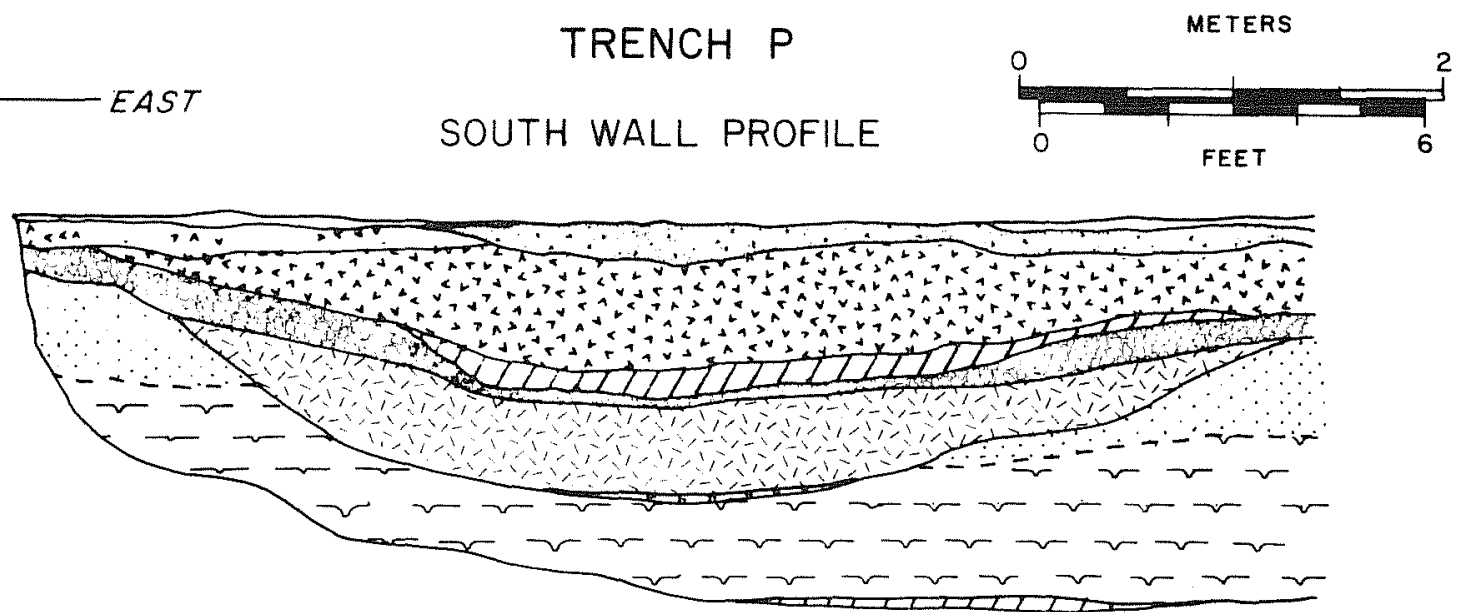

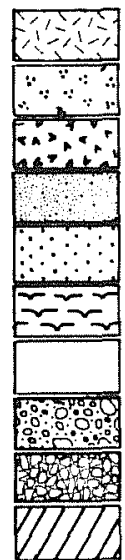

DARK SOILS WITH CULTURAL, SNAIL DEPOSIT

CHARCOAL, SNAIL CONCENTRATION

$41 \mathrm{BX} 337$

GRAY, BLACK CLAYEY SOIL

LOOSE SANDY SOIL

BLACK CLAYEY LOAM

BROWN CLAYEY LOAM

BROWN TOPSOIL

YELLOW GRAVELS

CALICHE PEBBLES

CALICHE

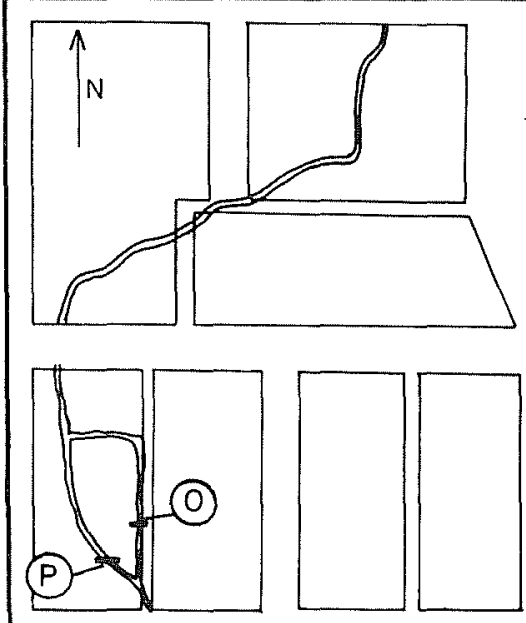

Figure 10. Soil Profiles of Trench $O$ and Trench $P$. 


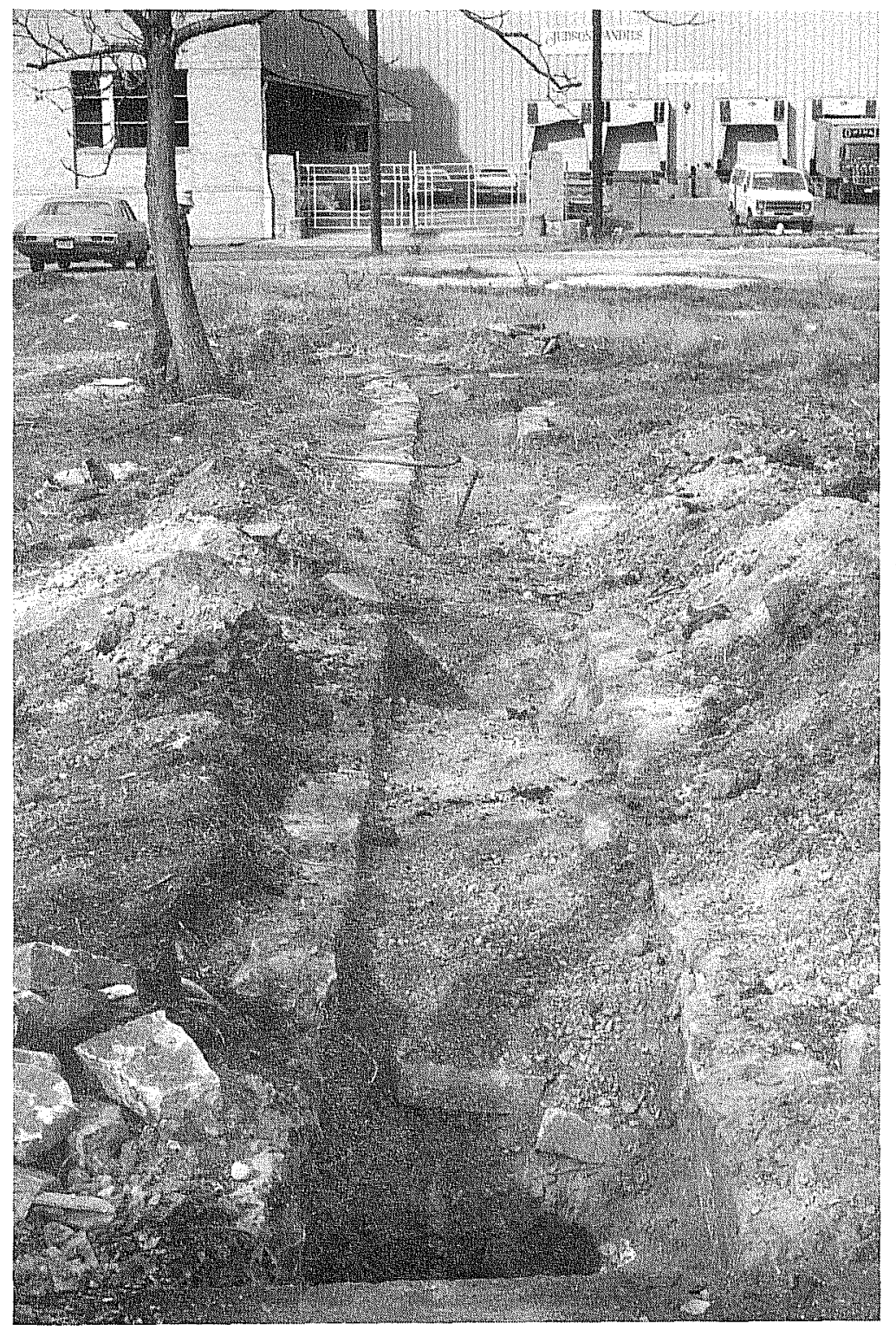

a

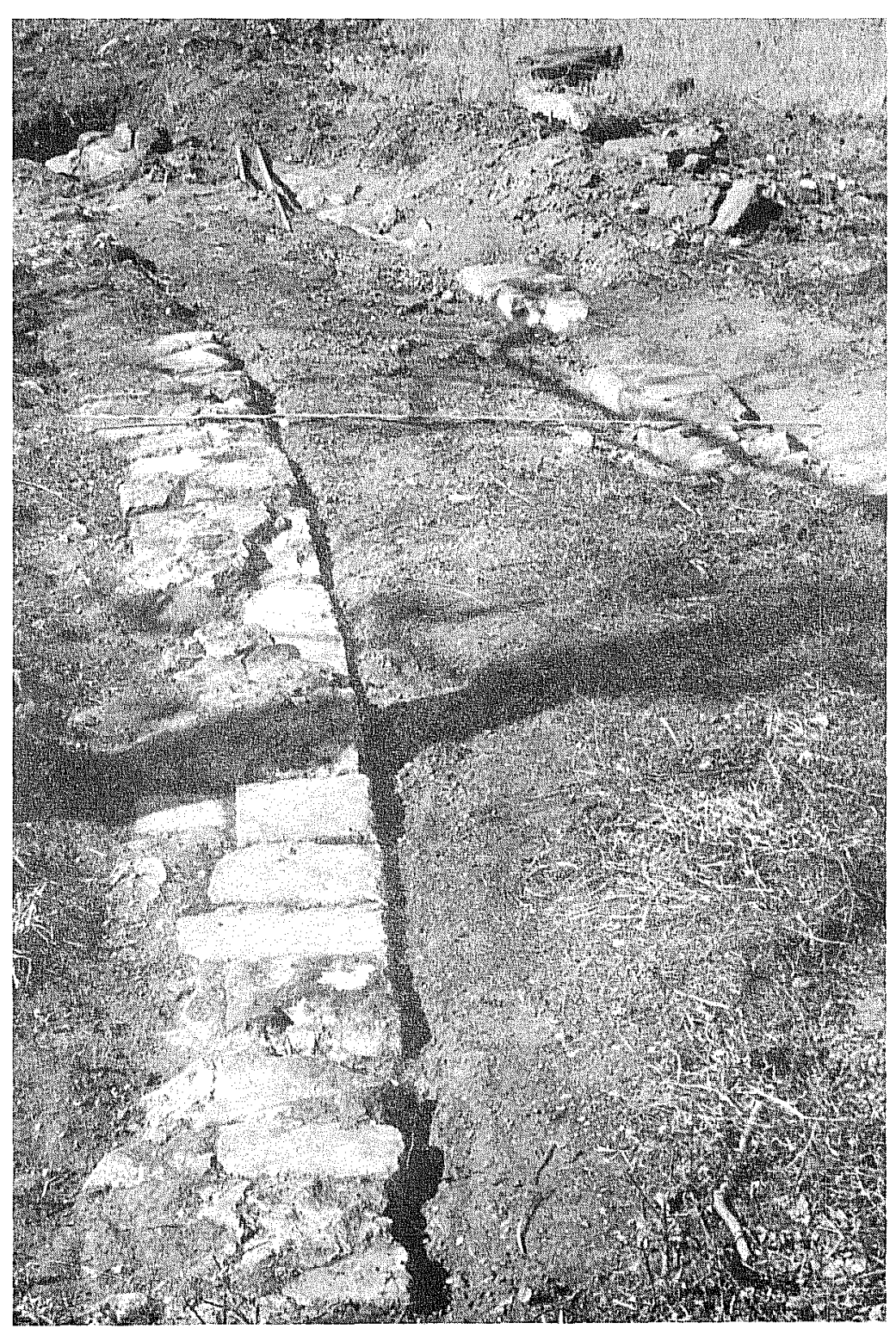

b

Figure 11. San Pedro Acequia. a, stone-lined portion of acequia in excavation Trench F; b, stone-lined acequia in excavation (surface) Trench $Q$. 
photographed (Fig. $11, \mathrm{~b})$, and it was noted that the stone masonry was a different style. A collection of small limestone blocks with occasional clay bricks were mortared together in different localities along the top; this later work could suggest that the wall height was raised to accommodate a higher water level.

The surface overburden consisted of a layer of asphalt over a caliche fill. Other portions of the trench were covered with topsoil and grass. The west end of Trench $Q$ uncovered a disturbed area. This disturbance displaced some of the limestorie block on both sides of the acequia. It is very likely that a sewer line was trenched through the acequia walls at this point. Artifacts that were selected from the surface indicated that the surface had not been exposed for any great length of time before a covering was placed over it.

\section{Trench $R$}

Trench $\mathrm{R}$ was located at the stone-1ined portion south from Trench 12 to a distance of 20 feet (Fig. 2). The trench area was covered with a layer of asphalt and caliche and is presently used as a parking lot. The backhoe was used to clear this heavy overburden which averaged 9 inches in thickness. The remaining few inches above the acequia stones were cleaned by hand and the surfaces of the acequia walls were brushed clean and photographed. The masonry work consisted of large limestone blocks and each block contained chisel marks on the face. The few artifacts collected were contemporary in date with those found on the surface in Trench Q. 


\section{THE ARTIFACTS}

A11 of the materials recovered in the field from Phase I and Phase II excavations were removed to the laboratory for analysis. The specimens were cleaned, identified, described, classified and cataloged. The artifacts are presented by categories (ceramic, glass, metal, etc.) and the quantities collected are indicated. They are listed according to the trench in which they were found. Selected artifacts are illustrated in Figures 12 to 18 . All materials are stored at the Center for Archaeological Research 1aboratory.

One of the most useful tools the archaeologist has for dating historic sites is the pottery recovered during the investigations. In addition to the form, decoration and paste, a potter's mark (Fig. 17) is very useful for identification and dating. Many of the identified pottery wares described below have potter's marks to indicate that they were made here or were imported from Europe, mostly from England.

Other artifacts used by the archaeologists for dating are glass bottles. Soda water bottles of the late 19th century, for example, frequently had the name and address of the bottle maker embossed on the side or bottom (Fig. 12 and Fig. 16a,b). By using an old city directory, the approximate dates of when the business was established and when it was terminated can often be determined. A bottle found in an old refuse deposit, which can be identified by the markings, was probably discarded during the time the bottle maker was in business, thus giving an approximate date for the bottle and the associated debris. 0ther bottle indicators useful for dating include the color of the glass and the seam marks. The earliest bottles were hand-blown. Later the bottles were formed in a mold and the neck and mouth applied by hand. Eventually the entire bottle was molded in one operation. With the development of the molds, seam marks changed in length through time, providing additional indicators which are datable.

There is a great deal of literature on the subject of old pottery and glass available for the archaeologist to refer to during analysis, and many of the artifacts described here were identified by referring to the literature. Much of the pottery and glass, and many other artifacts, have been identified by Anne A. Fox, who has kindly introduced the author to the subject 1iterature.

\section{Trench 1}

\section{Ceramics}

Earthenware; white paste, clear glaze

2 sherds, undecorated

1 lavatory bas in fragment

\section{Trench 3}

\section{Ceramics}

Red paste

1 fragment of tile, unglazed 


\section{Porcelain}

1 sherd, undecorated

2 sherds, hand-painted

Glass

1 smal1 jar-type bottle

1 small long-neck bottle

1 green hand-blown wine bottle (Fig. 16,d)

Meta 1

1 wire nail

Miscellaneous

7 large mammal bones

Trench 7

Ceramics

Red paste

1 sherd, unglazed, flower pot

Earthenware; white paste, clear glaze

1 sherd, undecorated

1 sherd, molded decoration

Porcelain

1 sherd, undecorated

Glass

1 aqua bottle neck fragment with handle fragment (Fig. 14,g)

1 aqua bottle neck fragment

1 green bottle with embossed lettering, WORCESTERSHIRE SAUCE

1 handle fragment from a molded glass pitcher

Metal

1 clock spring winding key (Fig. 18,i)

Miscellaneous

1 large mammal bone 
Trench 11

Ceramics

Porcelain

2 sherds, hand-painted

Stoneware

1 jug base fragment with Bristol glaze exterior and Albany slip interior

1 rim sherd Rockingham glaze exterior

1 jug base fragment with salt glaze exterior and brown glaze interior

Glass

1 circular base of a stemmed glass

2 green bottles with "wittle marks" and embossed lettering on the base. SAXLEHNERS / BITTERQUELLE / HUNYADI / JANOS / (Fig. 13,d) and (Fig. 16,c). Andres Saxiehner was an interesting figure in history whom the bitter bottle was made to honor. Toulouse (1971:257) gives the dates 1863 to $\mathrm{ca} .1900$ when these bottles were made.

1 blue Coca Cola bottle bottled in San Antonio, Texas with a 6 oz. capacity

1 clear soda bottle with TEJAS BEVERAGE printed on the side, 10 fluid oz. capacity

1 small green long-neck bottle with embossed lettering MRS. WINSLOW / SOOTHING - SYRUP

2 clear small long-neck cologne bottles

1 blue jar-type bottle with embossed lettering BROMO / CAFFINE

1 green flask bottle

Metal

1 spark plug with printing AUTO / LITE

1 hacksaw blade

11949 Texas license plate

1 brass sword hilt (Fig. 18,j)

Miscellaneous

5 large mammal bones

5 hackberry seeds

Trench 12

Glass

1 white salve jar with embossed lettering on the base MENTHOLATUM / RED TRAD / MARK

1 brown bottle neck fragment (Fig. 14, h) 
Metal

1 rusted can key (Fig. 18,h)

Miscellaneous

1 bakelite knife handle fragment

2 half shells of oyster

3 large mammal bones

Trench $B$

Glass

1 aqua flask bottle with embossed lettering WYCKOFF \& COS / UNION / BLUING (Katz 1978:62; Fig. a)

1 clear flask type bottle with embossed lettering THE / ROYAL REMEDY / \& / EXTRACT CO. / DAYTON, OHIO (Fig. 12,d)

Trench $\mathrm{C}$

Ceramics

Red paste

2 lead glazed with one piece decorated galera ware (Gilmore 1974:

plates 16,17 )

Earthenware; white paste, clear glaze

1 sherd undecorated

2 sherds flown blue decorated

1 sherd brown transfer decorated under glaze, maker's mark incomplete ENGLAND / CO.

1 tea pot spout undecorated

1 tea pot spout with Rockingham Glaze

\section{Stoneware}

1 sherd with Albany slip interior and salt glaze exterior

1 ink bottle with exterior slip and impressed lettering along the base; CARTER'S INKS (Fig. 17,a) Pottery ink bottles were produced by J. Bourne for Prang and Carter Ink Companies. These bottles were cream colored or white (Munsey 1970:135). Edwards (1971:103) wrote that ink bottles of J. Bourne were made from 1833-1861.

\section{Glass}

1 clear decanter bottle fragment with glass stopper (Fig. 13,b) (Fig. 14,C)

1 clear glass stopper with mold seams on stem

1 aqua bottle neck (Fig. 14,a) 
1 clear bottle neck with embossed lettering on body fragment OMPS, which probably is part of the word Thompson (Fig. 14,i)

1 green bottle fragment

1 aqua bottle with embossed lettering FLORIDA WATER / MURRAY \& LANMAN / DRUGGISTS / NEW YORK (Fig. 12,f) (Munsey 1970:157)

1 clear soda water bottle with embossed lettering DUERLER / SAN ANTONIO / TEX. / (Fig. 16,a)

1 clear flask medicine bottle with embossed lettering J. D. DEVINE / DRUGGIST / SAN ANTONIO, TEX. (Fig. 12,a)

1 brown syringe with iron shaft and a $4 \mathrm{ml}$ capacity (Fig. 12,e), (Fig. 18,f)

Metal

1 brass lantern burner (Fig. 18,b)

Miscellaneous

1 buff-colored chert perforator associated with the prehistoric occupation level south of the acequia profile

Trench $D$

Ceramics

Stoneware

1 sherd Meyer Pottery with Leon slip interior and exterior

1 ink bottle base with glaze exterior VITREOUS STONE BOTTLE --1 (Fig. 17,e) WARRANTED NOT TO ABSORB / J. BOURNE / PATENTEE / ENBY \& CODNER-PARK POTTERY / NEAR DERBY / . J. Bourne made containers for the Arnold Ink Company (Munsey 1970:135).

Earthenware; white paste, clear glaze

1 sherd, undecorated with maker's mark (Fig. 17,f), Goodwin Pottery Co. of East Liverpoo1, Ohio produced pottery from ca. 1844-1893 (Barber 1904:105)

1 sherd undecorated with maker's mark (Fig. 17,C), John Maddock and Sons of England made Royal Semi Porcelain from 1855 to ca. 1906 (Godden 1964:406)

1 sherd undecorated

1 sherd edgeware

1 sherd blue floral decal over glaze

Glass

1 fragmented brown snuff bottle

1 green insulator fragment with numbers embossed on the top $359 /$

1 aqua panel bottle with embossed lettering DIRECTIONS / IN THE / PAMPHLET (Fig. 12,b)

1 green bottle neck fragment (Fig. 14,e) 
1 aqua panel bottle with embossed lettering GORDONS / DRY GIN / ENGLAND (Fig. 13,c) (Munsey 1970:131)

1 blue jar type bottle with embossed lettering BROMO - SELTZER / EMERSON DRUG C0. / BALTIMORE, MD. (Fig. 12,c) Toulouse (1971:339) writes the first bottles were being produced since 1916 .

Metal

1 iron ice cream dasher frame (Fig. 15,d)

Trench Area $C$ and $D$

GTass

1 brown homeopathic bottle with a capacity of 4-1/2 drams (8-1/4 m1)

1 clear homeopathic bottle with a capacity of 4-1/2 drams

1 aqua jar base

1 brown bottle neck (Fig. 14,b)

Trench $F$

Ceramics

Earthenware; white paste, clear glaze

1 sherd green floral decal over glaze

1 sherd molded swirl decorated

Porcelain

1 sherd hand-painted red

1 sherd hand-painted gold

Stoneware

3 jugs with Bristol glaze exterior and Albany slip interior

Miscellaneous

1 twelve gauge shotgun shell, brass with inscribed lettering and removable primer WINCHESTER / NO. 12 / REPEATER. The primer reads W.R.A. CO. / NEW NO. 4 / Robert Patton (personal communications) dates this ammunition ca. 1920 . (Fig. 18,d)

1 lead mini ball measuring 60 caliber (Fig. 18,C)

Trench Area $E, F$ and $I$

Ceramics

Stoneware

1 jug fragment with Bristol Glaze exterior and Albany slip interior 
1 sherd with salt glaze exterior and Albany slip interior

Earthenware; white paste, clear glaze

1 plate sherd undecorated

1 sherd green decal with gold trim underglaze

1 sherd undecorated with maker's mark (Fig. 17,d)

1 sherd undecorated with maker's mark (Fig. 17,b). Stuebenville Pottery Company from Stuebenville, Ohio established in 1879 (Kovel and Kovel 1953:155)

Glass

1 green food jar with embossed lettering on the base (Fig. 13,a). Toulouse (1971:278) dates John Kilner Sons in Wakefield, England, bottling in 1844

1 aqua ink bottle

1 clear flask bottle with cork stopper, capacity of 4-fluid ozs.

1 clear panel liquid veneer bottle with a capacity of 3/4-fluid ozs.

1 clear wide mouth bottle with a capacity of 1-fluid oz.

1 clear hair tonic bottle with a capacity of 8-fluid ozs.

1 white salve container with manufacturing company mark on the base CHESEBROUGH MFG. CO. / N.Y.

1 aqua beer bottle with manufacturer's name on the base (Fig. 13,f) Adolphus Busch Glass Manufacturing Co. manufactured bottles from 1904 - 1907 (Toulouse 1971:26)

Trench I

Glass

1 green soda bottle with embossed lettering DUERLER / SAN ANTONIO / TEXAS. A Hutchinson stopper, popular in the 1890s, is trapped inside the bottle (Fig. 16,b) (Munsey 1970:104)

Trench $J$

Ceramics

Stoneware

1 sherd with a clear glaze interior and exterior

Earthenware; white paste, clear glaze

1 sherd with no decorations

Glass

1 clear flask bottle with embossed lettering on the base and a capacity of one pint which makes it a probable whiskey flask (Fig. 13,e) 
T clear cologne type bottle capable of holding 2-1/2 fluid azs.

1 brown square snuff bottle

1 blue Bromo-Seltzer bottle as found in Trench $C$

1 aqua bottle neck fragment (Fig. 14,d)

1 white salve jar lid fragment with embossed lettering on the interior AR CO. / WACO TEXAS

Trench $N$

Ceramics

Earthenware; white paste, clear glaze

1 sherd undecorated (Fig. 17,g). The maker's mark is the Johnson Brothers, England which is dated ca. 1913 and later (Godden $1964: 356)$

Meta 1

1 iron horse shoe (Fig. 15,a)

Trench 0

Meta 1

1 iron chise 7 measuring $8-1 / 2$ inches 1 ong and tapered on one end (Fig. 15,c)

Trench $P$

Ceramic

Red Paste

1 sherd unglazed slipped

1 sherd unglazed brick fragment

Stoneware

1 sherd green glaze on the exterior and interior

Earthenware; white paste, clear glaze

1 sherd undecorated

Glass

3 green bottle fragments with ESTERSHIRE / RRINS embossed lettering (Fig. 14,j). These fragments are of a large restaurant size bottle of Lea \& Perrins Worcestershire Sauce 
Metal

1 iron muleshoe with nails attached (Fig. $15, \mathrm{~b}$ )

Trench 2

Ceramics

Earthenware; white paste

2 sherds with green glaze

Glass

1 marble with red, white, and yellow colors

1 aqua bottle with embossed lettering on the base. The lettering reads W 2 / 36 which dates before the year 1900 (TouTouse 1971:531)

Meta 1

1 rectangular brass brooch (Fig. 18,a)

1 copper pocket watch chain (Fig. 18,g)

Trench $R$

Metal

Two piece copper military overcoat button with a shielded eagle emblem (Fig 18,e) 


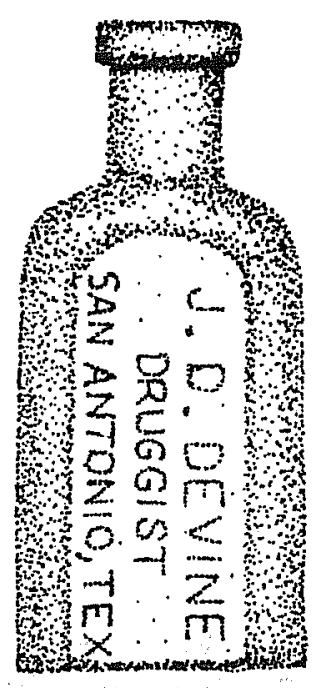

a

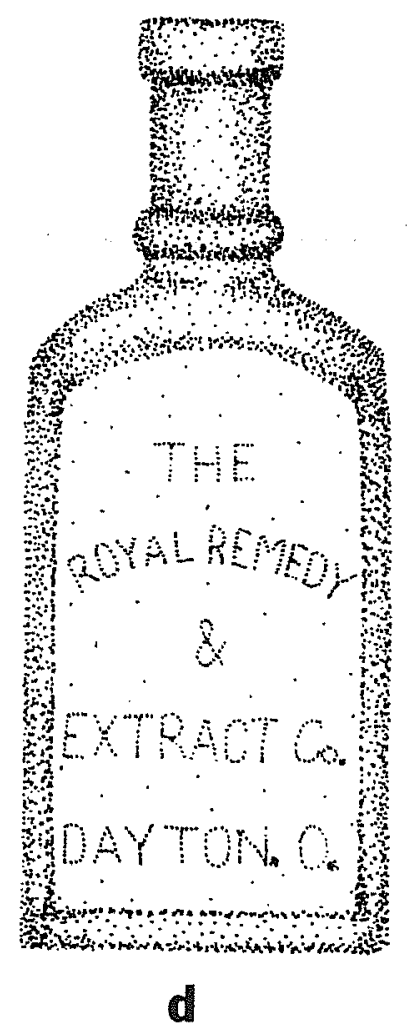

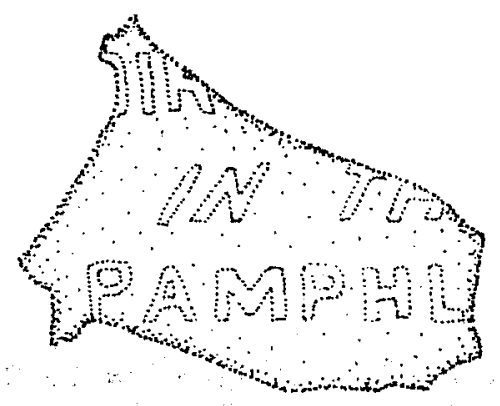

b
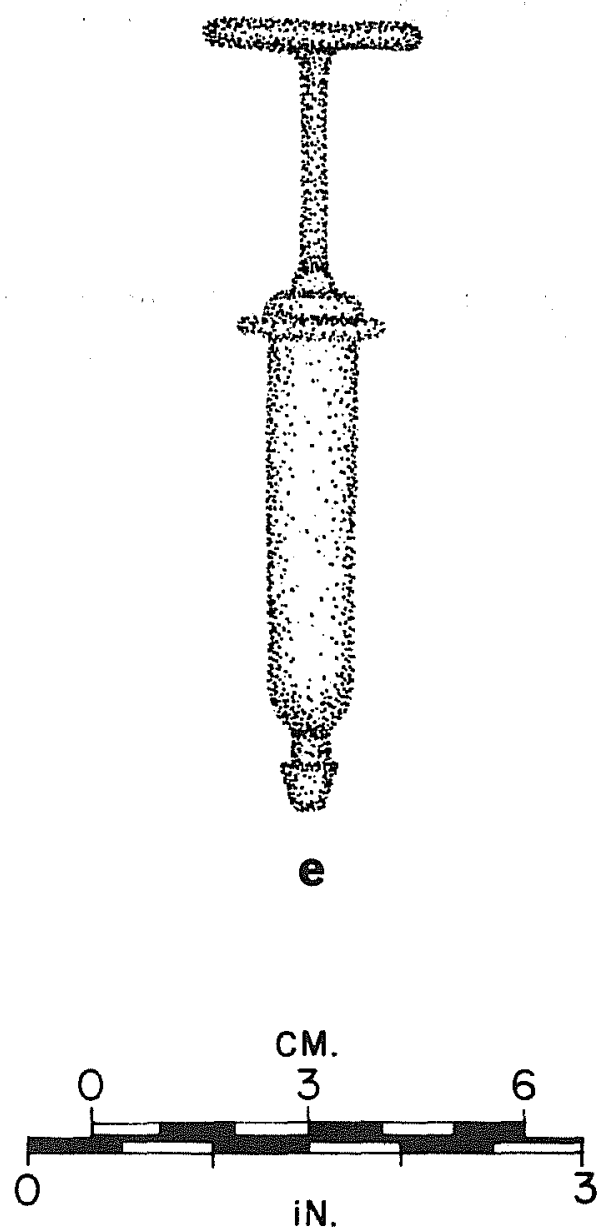

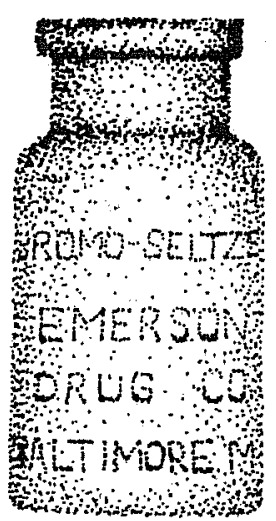

c

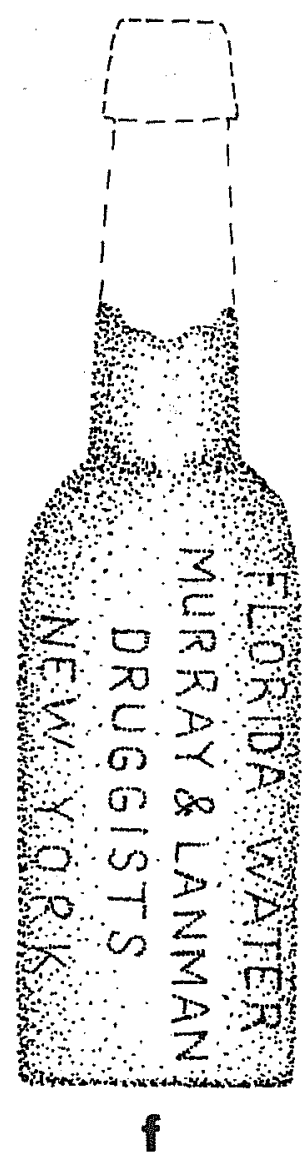

Figure 12. Selected Pharmaceutical Artifacts from the San Pedro Acequia. a,e,f, Trench C; b, c, Trench D; d, Trench B. 


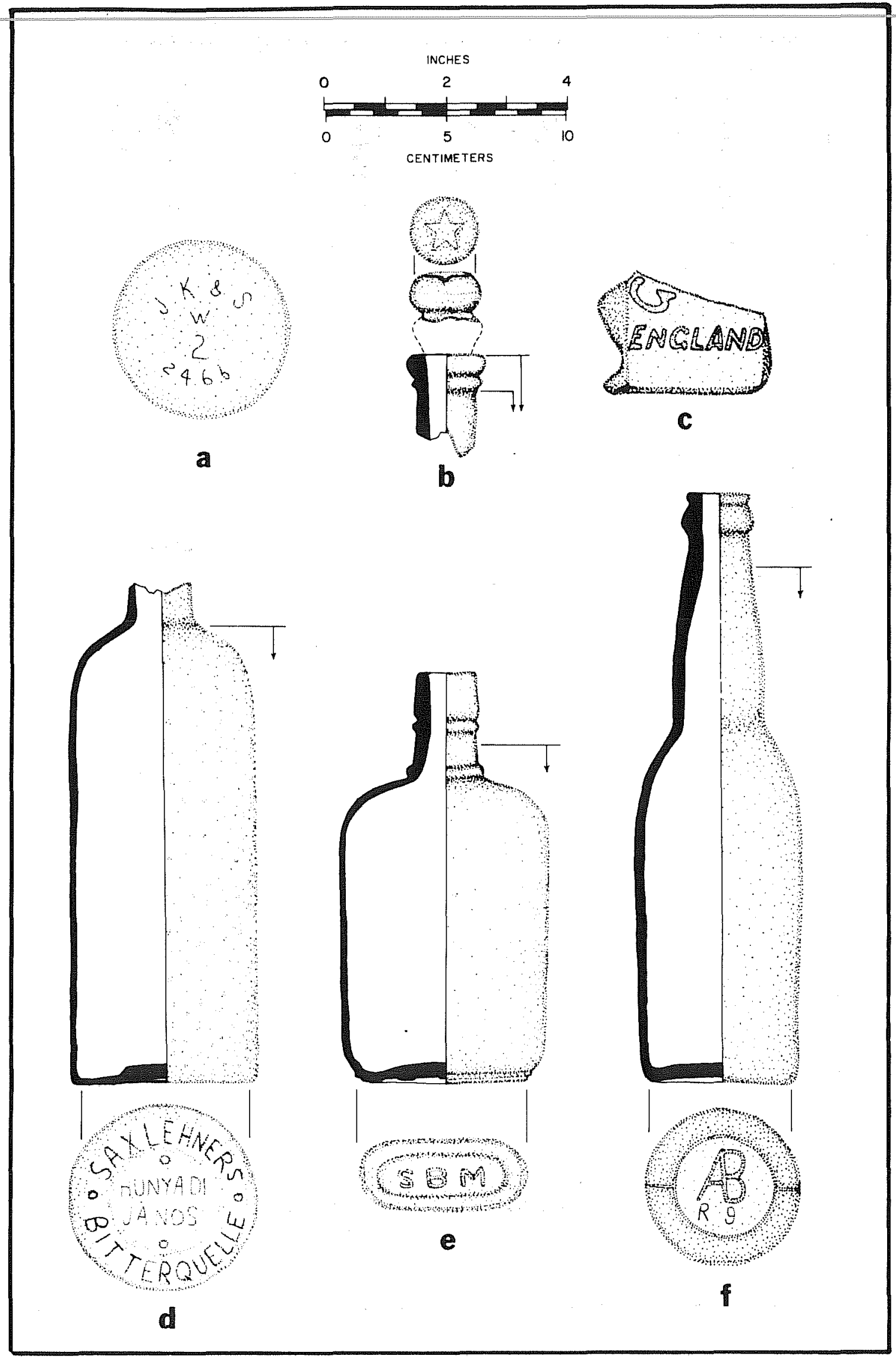

Figure 13. Selected Glass Containers. a,f, Areas E, F, I; b, Trench C; c, Trench D; d, Trench 11; e, Trench I. Note arrows depicting seam height. 

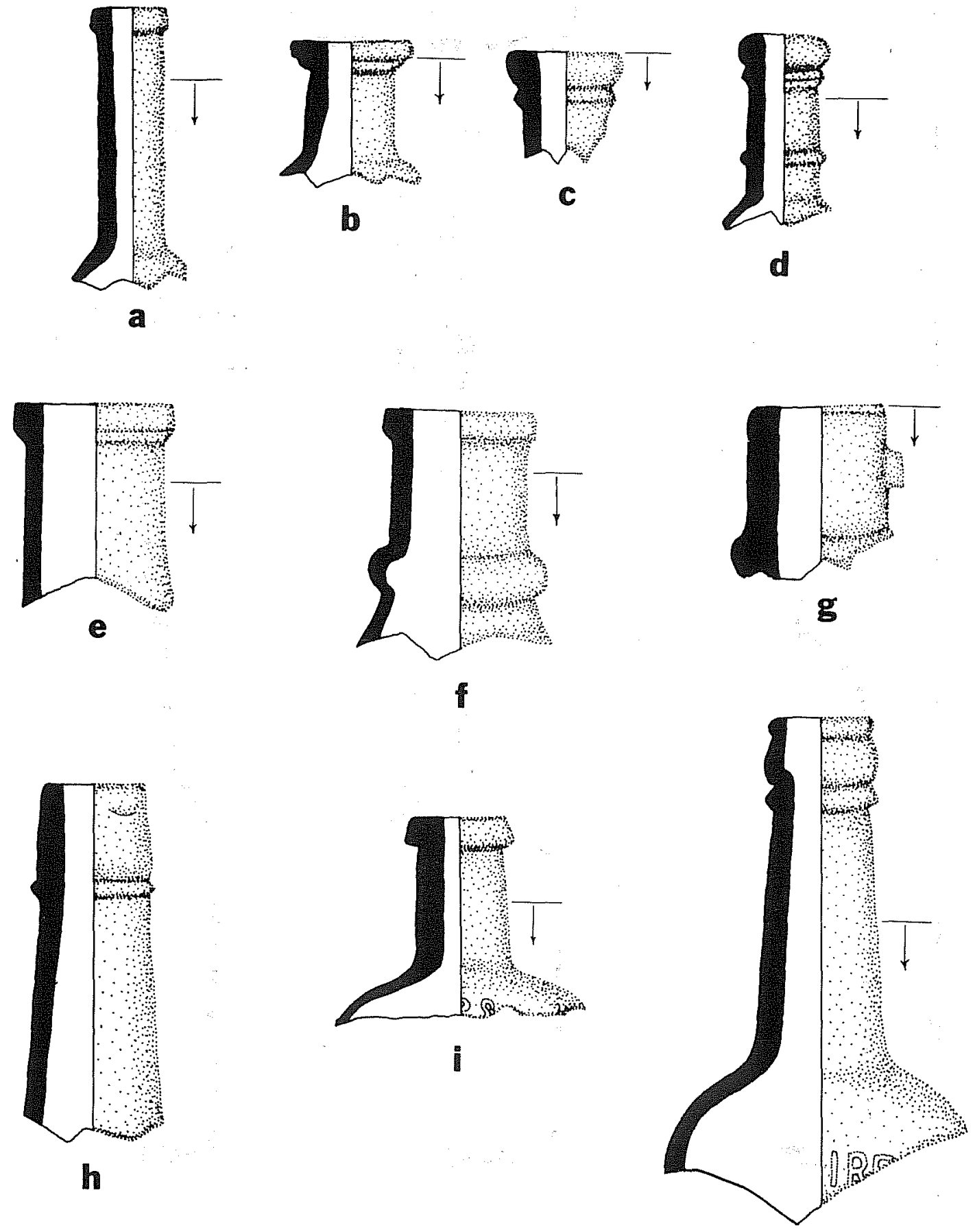

centimeters
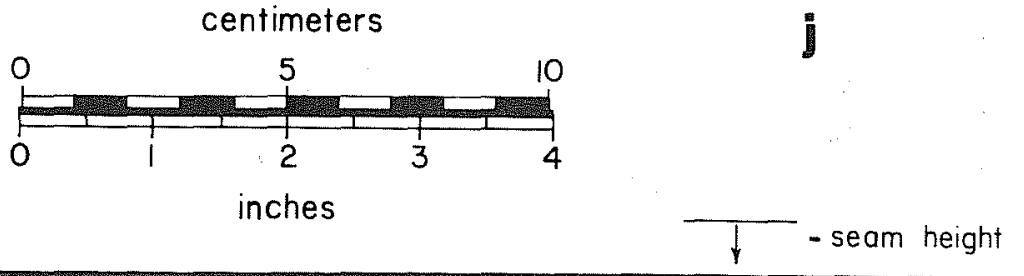

Figure 14. Selected Glass Artifacts Using Seam Height as a Time Period Indicator. a,,$i$, Trench $C$; b, Areas C-D; $d$, Trench I; e, Trench D; $f$, provenience unknown; $g$, Trench $7 ; h$, Trench $12 ; j$, Trench $P$. 


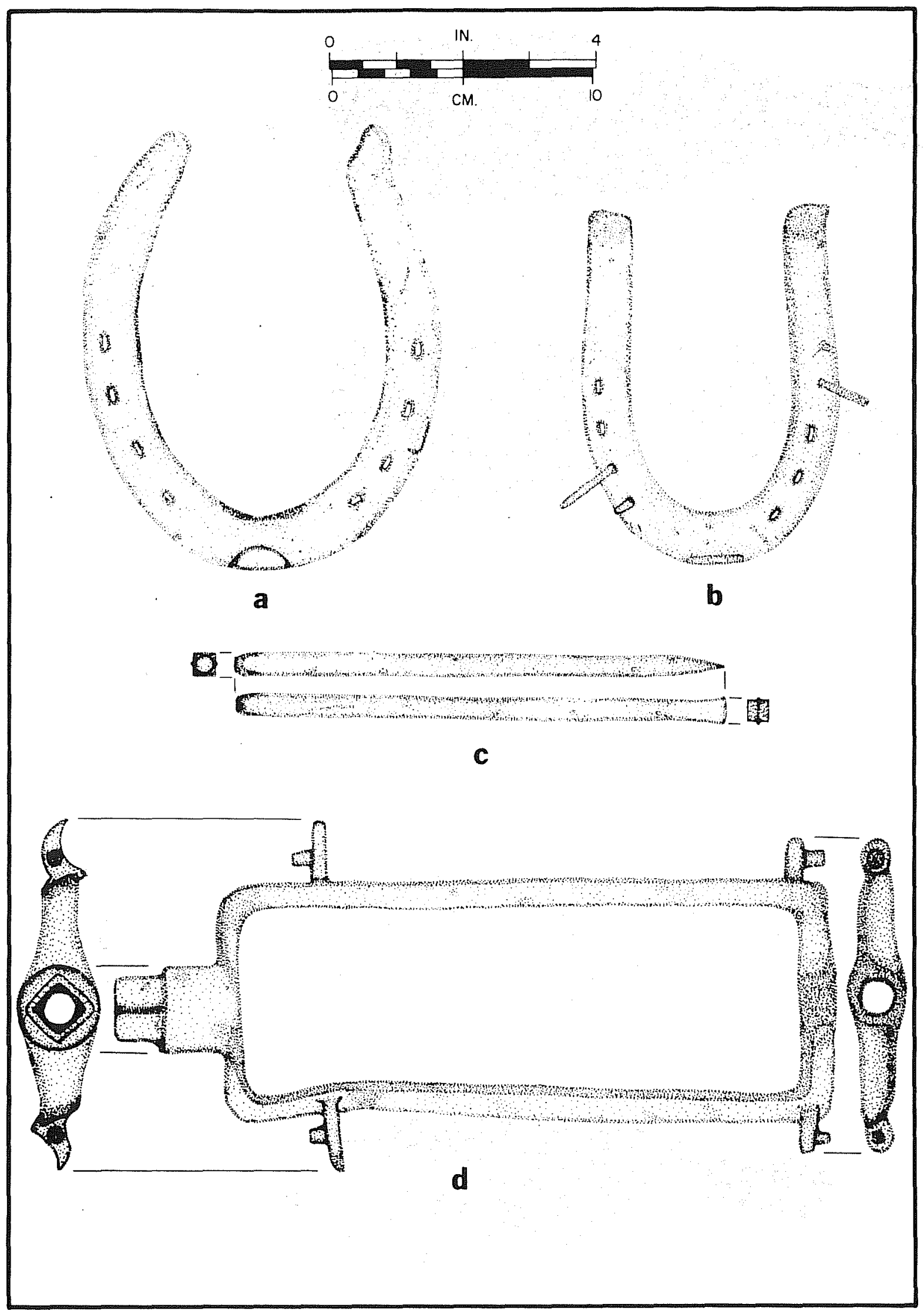

Figure 15. Selected Metal Artifacts. a, Trench N; b, Trench P; c, Trench 0; d, Trench D. 


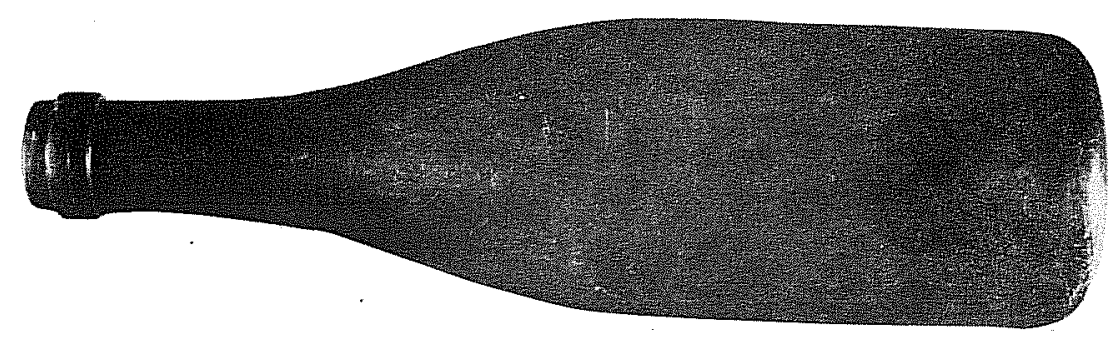

8

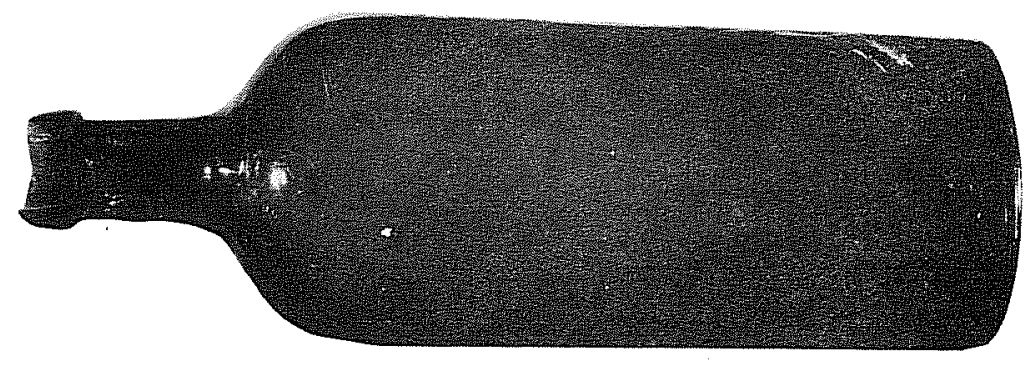

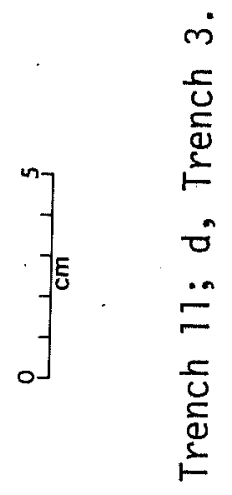

0
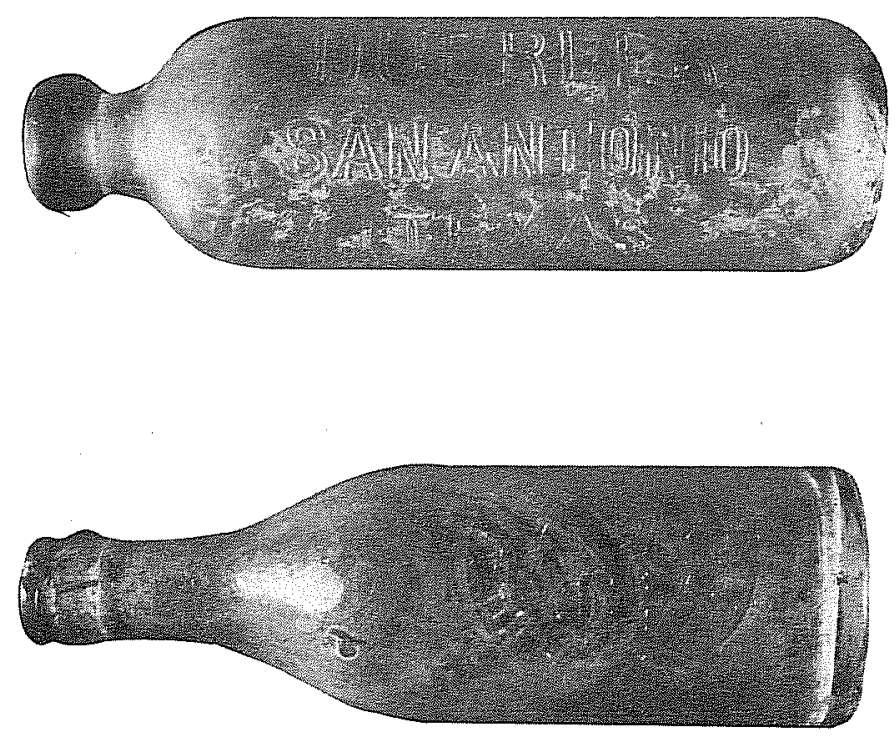

a

10

ค

ن

兘

i

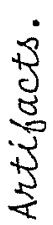

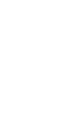



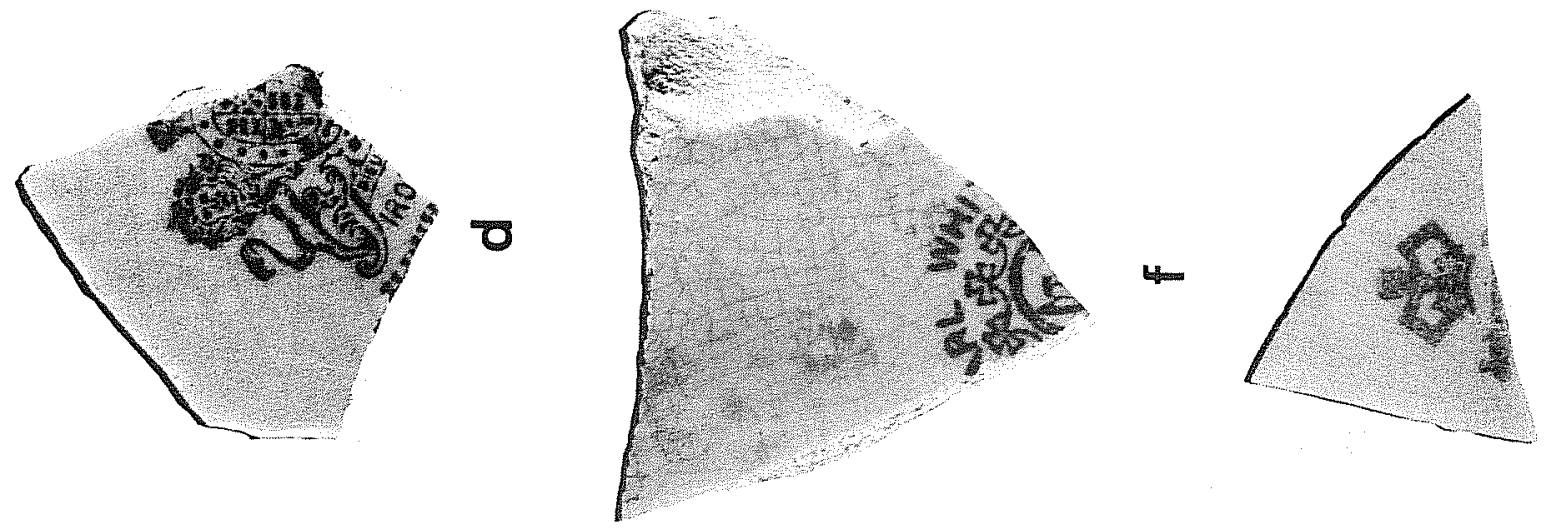

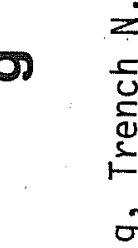
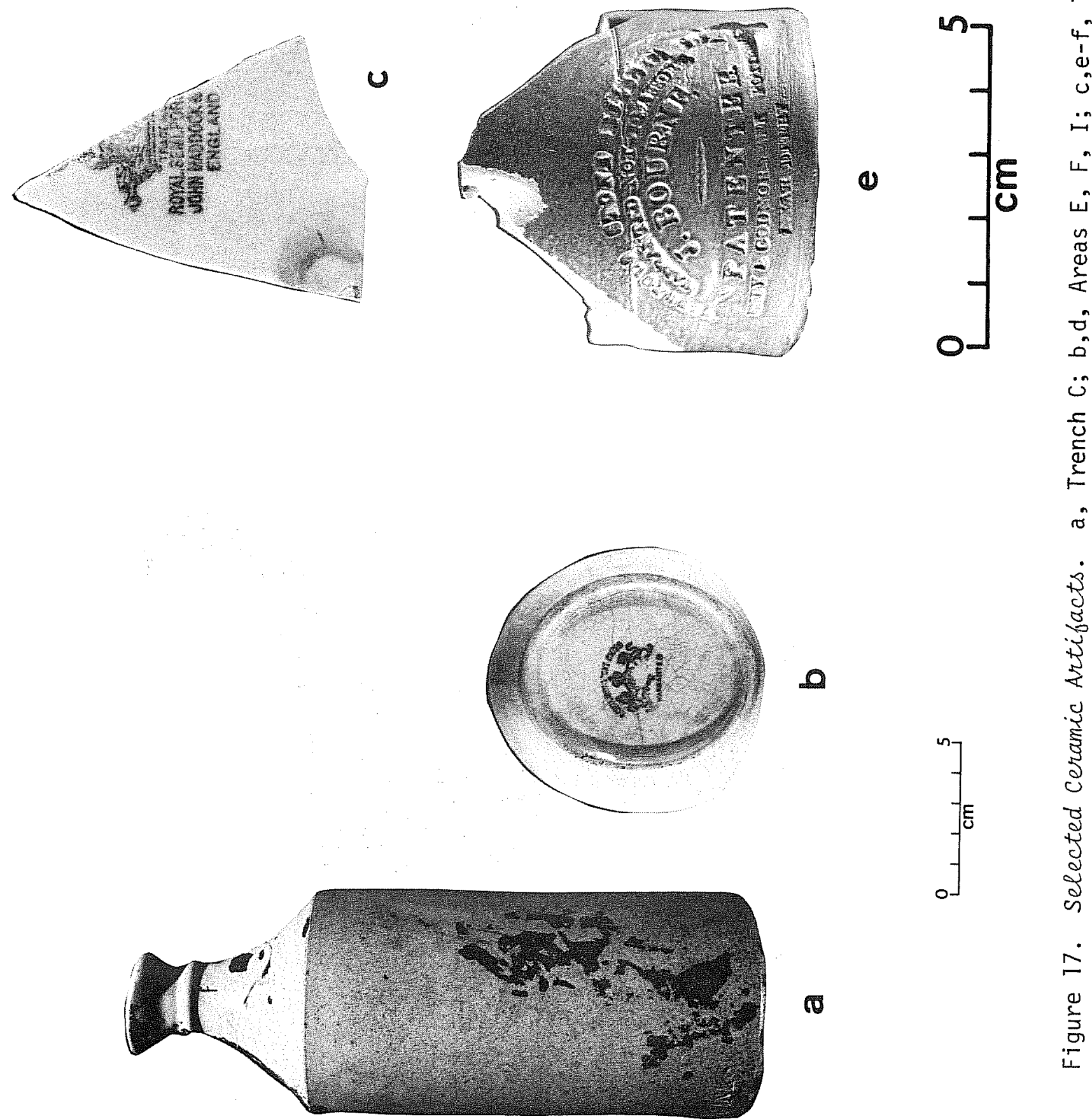

(6)

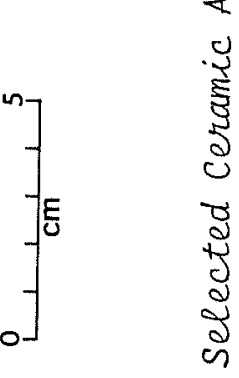




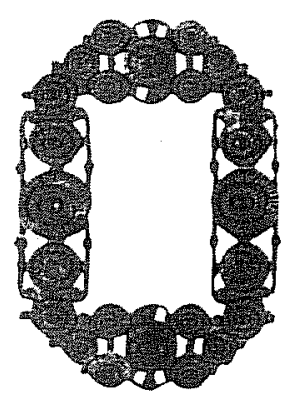

a

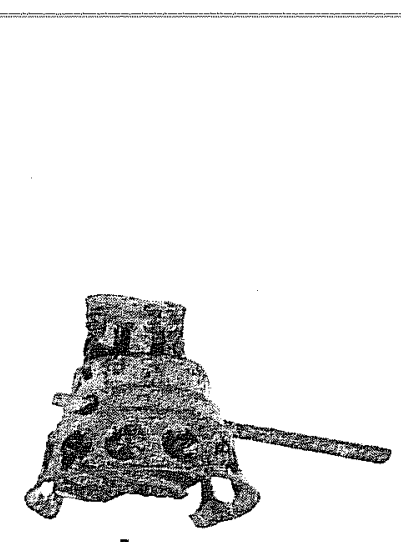

b

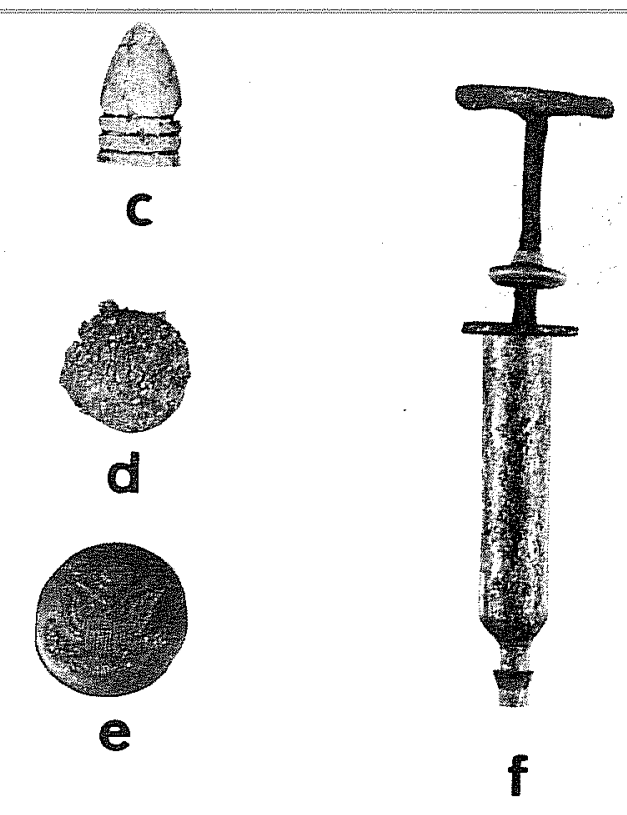

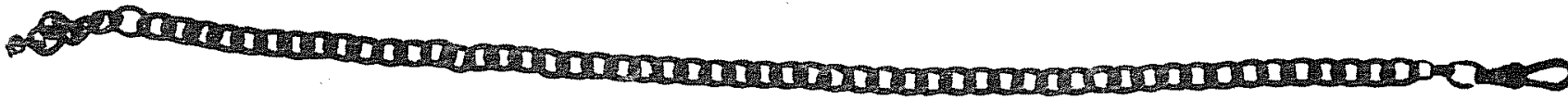

9
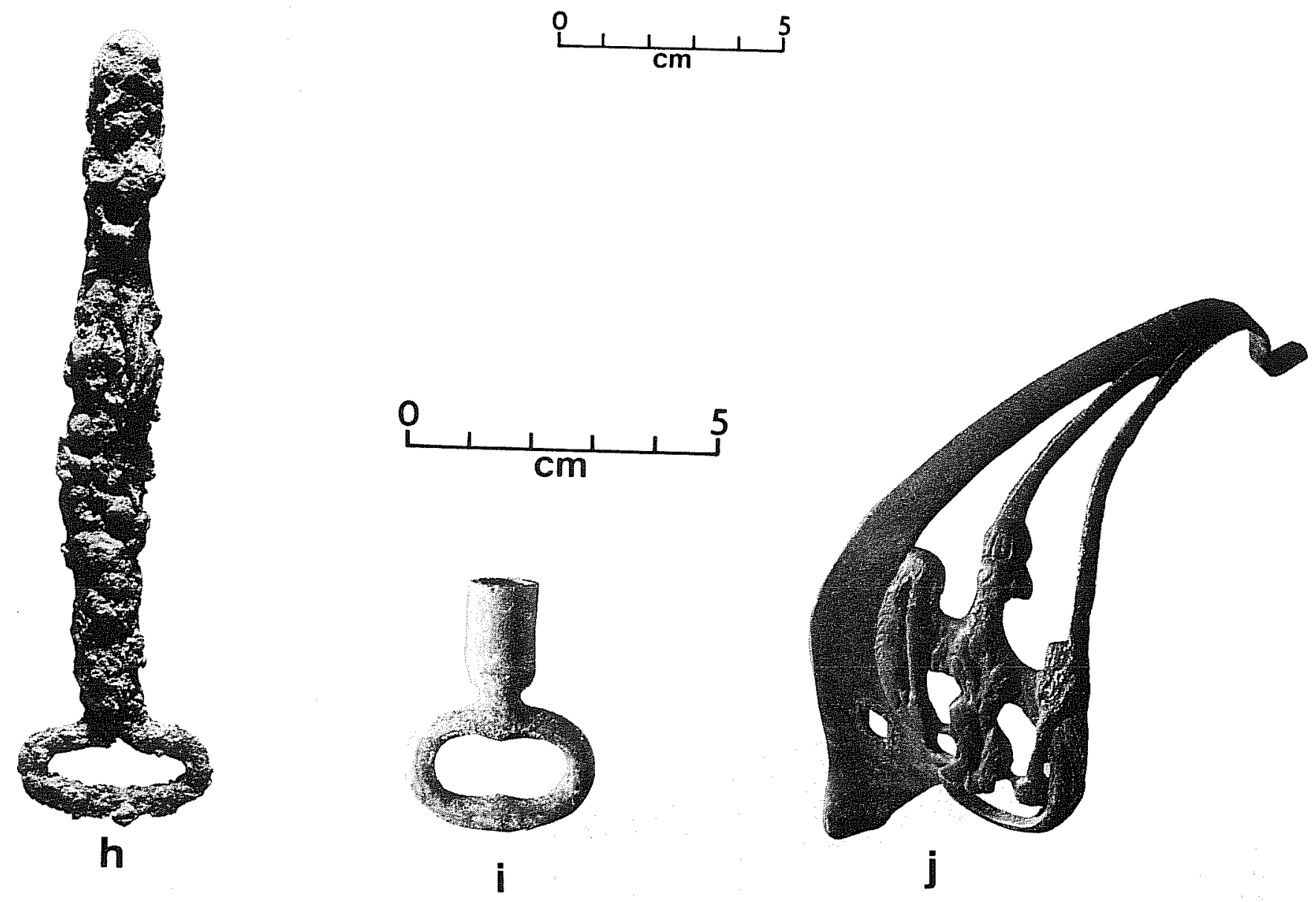

Figure 18. Selected Metal Artifacts. a,g, Trench Q; b,f, Trench C; c-d, Trench F; e, Trench R; $h$, Trench 12; $i$, Trench $7 ; j$, Trench 11 . 


\section{CONCLUSIONS}

In the course of archaeological investigations, both in Phases I and II, a tota 1 of 31 trenches were dug on GSA property. Of the 31 trenches, 21 were found to contain traces of the San Pedro Acequia. The profiles described in this report suggest that three major periods of construction or modification are represented. The first period of acequia construction is represented by an unlined ditch. This is supported by the profiles observed in Trenches $1,3, \mathrm{~J}, 7, \mathrm{D}, \mathrm{C}, \mathrm{B}, \mathrm{I}$, and $P$. These trenches trace the acequia as it enters the GSA property at $W$. Sheridan Street. The acequia route runs south for ca. 150 feet and then turns to the southwest, crossing the south end of Calvert Street. The acequia takes a westward direction for about 50 feet, and then turns southwest. The ditch follows this direction to the corner of $W$. Johnson and S. Flores Streets. The acequia extends south, crossing W. Johnson Street, and continues south for ca. 190 feet. It then takes a southeast direction, where it leaves the GSA property some 150 feet east of S. Flores Street along W. Guenther Street.

The majority of support in determining the periods of construction was derived from historical documents, ethnographic accounts, and maps or photographs. The artifactual material representing the earliest age of the acequia is very $1 \mathrm{im-}$ ited. The lack of 18th century artifacts can possibly be explained by the early historical accounts. We know that the area in the 18th century consisted of open fields, located away from the main area of population and activity. Additionally, it is known that the acequias were periodically cleaned.

When the population pushed south of Main Plaza, the need for control over the . water of the acequia became greater. Improvements on the acequia were continuous. Small feeder channels to irrigate an individual's land were added when needed. The improvements for a more maintenance-free water system can be seen by the cedar post and plank support structures. These structures were probably placed throughout the acequia wherever they were needed to slow down the erosion of its banks. As the population intensified, the need for flood control and reclamation of the land became more important. The construction of limestone block channel walls improved the water distribution. The block construction is represented by the evidence uncovered in Trenches $A, C, E, F, G, H, K, Q$, and 12. The route of the stone-Tined portion appears to begin in Trench $C$, where it joins with the unlined portion. The stone-lined portion runs east to the west side of the Calvert Street extension. At this point it appears to make a $90^{\circ}$ turn east and travels ca. 85 feet, where it begins to make a southeast curve to a point 45 feet west of S. Flores Street and W. Johnson Street. The stone-lined portion is probably occupying the same trench dug for the original acequia. Trench $\mathrm{K}$ on the south side of $W$. Johnson Street reveals what looks like the south end of the limestone block construction.

The path of the stone-lined portion of the acequia gives the appearance of following certain property lines. This would suggest that the rerouting of the acequia was done to develop the area for residential or business occupation. This can be observed by the remains of concrete building foundations and asphalt paving in the area. Artifacts usually associated with the household (i.e., kitchen refuse) represented the vast majority of the items recovered. An advertisement sign for used cars nearby and the numerous old automobile parts observed in the acequia indicate that a used car business occupied this area at one time. The occurrence of what appears to be large fragments of limestone slabs suggests that they were 
used as a covering over the stone-lined portion. Historically, we know that the acequia was covered in the areas of heavy pedestrian traffic. This covering would prevent the type of artifact deposition which would occur in an open ditch. In other words, at the termination of the acequia's usage, the open acequia would accumulate soil and refuse first. The covered portion would stay protected until eventually or intentionally the covering was removed and the void filled. Tentatively, the artifacts support the sequence of the acequia modifications in this area. The artifacts from the trenches representing the reclaimed land are late 19th century, whereas the artifacts from the stone-lined portion suggest an early 20th century continuous deposit.

The final construction period is represented by the trenching activity south of $W$. Johnson Street. This acequia is a dirt-lined construction rerouted from the original acequia route. Trenches $M, N$, and 0 reveal the existence of the rerouted portion. The concrete foundations suggest that the land was reclaimed for building purposes. The rerouted ditch appears to intersect the original acequia 90 feet south of $W$. Johnson Street. From this point the main acequia travels east for ca. 100 feet. The ditch made a 90 turn south and paralleled an unmarked a 1ley for ca. 240 feet, where it rejoined the original path of the San Pedro Acequia. The original acequia route, which was filled to reclaim the land, should contain artifacts older than those accumulated in the rerouted portion. Unfortunately, the quantity of artifacts observed and collected in this area is insufficient to determine any more than a tenuous sequence of dates for the two activities.

The time span represented by the acequia modifications is relatively short. The stone-lined construction is estimated to have been built about the same time as the rerouted unlined ditch south of $W$. Johnson Street. These constructions or modifications are estimated to have been finished at the turn of the 19th century. The San Pedro Acequia was closed in 1912 and was filled in about 10 years later. Specifically, the exact time each was filled was determined by the current necessity.

The San Pedro Acequia in the area of S. Flores Street and W. Johnson Street is documented to have a lateral, or branch. This branch is to have routed water to fields east of the San Pedro Creek and west of the main acequia. No evidence of this lateral was uncovered in the course of investigations. The actual junction is suspected to lie underneath $W$. Johnson Street. The possibility of any such evidence south of $W$. Johnson Street is slim, since that portion was probably eliminated by the water main trenching paralleling $S$. Flores street.

\section{RECOMMENDATIONS}

Historical research and archaeological excavations revealed that the original 18th century San Pedro Acequia traversed the GSA property (Fig. 2), and it has been recognized to have undergone two additional periods of modifications. The original route of the acequia is the most difficult segment to identify on the property since the width of the original ditch was found to be inconsistent due to its earthen construction and many subsequent alterations through maintenance.

The first period of acequia modification was the added stone-lined portion which was constructed to divert water from the original route. The dressed limestone block masonry reflects a construction tradition that was typical of the work done 
throughout San Antonio in the late 19th and early 20th centuries. This portion of the acequia is relatively well preserved; however, there are a few disturbed areas.

The second modification was the rerouting of the acequia below $W$. Johnson Street (Fig. 2). This rerouting is estimated to have been done about the same time as the installation of the stone-lined portion. The difference is that the southern rerouted portion is of earthen construction and was exposed for a relatively shorter time. Therefore, the route indicated in Figure 2 serves as the location of the archaeologically sensitive area along this portion. Any future land development should allow for adequate clearance on each side of the acequia.

As mentioned in the text, the GSA property is partly covered with concrete building foundations and asphalt. Some of the structural remains appear to have no basements and the removal of the foundations should be done with caution so as not to destroy the acequia that may lie beneath. It would be advantageous to the contractor if an archaeologist were to collaborate when the foundations were removed. In addition, any ground disturbance outside the sensitive areas of the acequia should be examined by an archaeologist. The possibility exists for small feeder channels or laterals in addition to late 18 th century house remains that might still exist for this area.

After reaching the end of its 1 ong and productive use, the San Pedro Acequia was buried. This has preserved the acequia's physical features, along with the cultural artifacts of its time, and a wealth of archaeological information still remains stored within the accumulation of soils inside the acequia.

\section{ACKNOWLEDGMENTS}

Numerous people helped to bring this project to a successful conclusion. The author expresses his thanks to the following persons. Dr. Thomas R. Hester, Director of the UTSA Center for Archaeological Research, served as Principal Investigator. Jack Eaton, Associate Director and Co-Principal Investigator, provided general supervision and aid in assembling the manuscript. Anne Fox and Jake Ivey provided assistance and advice during the artifact analys is and manuscript preparation. Carmen Perry of the John Peace Library at The University of Texas at San Antonio assisted in locating out-of-print books valuable for historical research. Guadalupe Gonzales shared his valuable time in showing me old surveying notes and plates, volumes of translated manuscripts, and many other archival documents. The staff working in the City Clerk's room helped in locating volumes of city council minutes. Manuel Cantu, of Cantu's Hauling Service, provided a transit and stadia free of charge, for locating and mapping all excavations and acequia positions. Blackie's Backhoe Service provided a backhoe with an operator whose precision made a hand-held shovel look slow and clumsy. 


\section{REFERENCES CITED}

Adams, R. E. W. and T. R. Hester

1973 Letter to Dr. Fred Wendorf, Chairman, Texas Antiquities Committee, concerning completion of excavations at Mission San Antonio de Valero, November 26.

Arneson, E. P.

1921 Early Irrigation in Texas. The Southwest Texas Quarterly, $X X V(2): 127-130$.

Barber, E. A.

1904 Marks of American Potters. Cracker Barrel Press, Philadelphia.

Bexar County Archives

1852 Commissioner's Court Records, Vo1. A-1, August 17.

Bolton, H. E.

1915 Texas in Middle Eighteenth Century: Studies in Spanish Colonial History and Administration. University of California Press, Berkeley.

Broussard, R. F.

1967 San Antonio During the Texas Republic; A City in Transition. Southwestern Studies, Monograph 18. Vol. V, No. 2. The University of Texas at E1 Paso.

Buck, S. M.

1949 Yanaguana's Successors. The Story of the Canary Islanders' Immigration into Texas in the Eighteenth Century. Naylor, San Antonio.

Casteñada, C. E.

1936 The Mission Era: The Winning of Texas, Our Catholic Heritage in Texas. Vol. II. Von Boeckmann-Jones, Austin.

Chabot, F. C.

1937 San Antonio and its Beginnings. Naylor, San Antonio. City of San Antonio

City Council Minutes, Journal A, May 15, 1847. 
City Council Minutes, Vol. E, December 5, 1879.

City Council Minutes, Vo1. E, November 16, 1880.

City Council Minutes, Vo1. V, September 3, 1912.

Corner, W.

1890 San Antonio de Bexar. Bainbridge and Corner, San Antonio, Texas. Cox, I. J.

1899 Founding the First Texas Municipality. The Texas State Historical Association quarterey II (3):217-226.

Dobkins, B. E.

1959 The Spanish Element in Texas water Law. The University of Texas Press, Austin.

Eaton, J. D.

n.d. Excavations at San Fernando Cathedra1, San Antonio, Texas. Center for Archaeological Research, The University of Texas at San Antonio. Manuscript in preparation.

Edwards, J., ed.

1971 Collector's Guide to Pottery and Porcelain Marks. John Edwards Publishing Co., Connecticut.

Fox, A. A., F. Bass, Jr. and T. R. Hester

1976 The Archaeology and History of Alamo Plaza. Center for Archaeological Research. The University of Texas at San Antonio, Archaeological Survey Report 16.

Fox, A. A.

1977 The Archaeology and History of the Spanish Governor's Palace Park. Center for Archaeological Research. The University of Texas at San Antonio, Archaeological Survey Report 31.

1978a Archaeological Investigation of Portions of the San Pedro and Alazan Acequias in San Antonio, Texas. Center for Archaeological Research, The university of Texas at San Antonio, Archaeological Survey Report 49.

1978b Preliminary Archaeological Assessment of South Parking Lot Area (Phase I) Site of Courthouse Annex, San Antonio, Texas. Letter Report to Bexar County Commissioner Court. 
Gilmore, K.

1974 Mission Rosario, Archaeological Investigations 1973. Texas Parks and Wildlife Department, Historic Sites and Restoration Branch, Archaeological Report 14(1).

Glick, T. F.

1972 The 01d World Background of the Irrigation System of San Antonio, Texas. Southwestern Studies, Monograph 35 . The University of Texas at El Paso.

Godden, G. A.

1964 Encyclopaedia of British Pottery and Porcelain Marks. Bonanza Books, New York.

Huesinger, E. W.

1936 Early Explorations and Mission Establishments in Texas. Naylor, San Antonio.

1951 A Chronology of Events in San Antonio. Standard Printing Company, San Antonio.

Holmes, W. H.

1962 The Acequias of San Antonio. Masters Thesis, St. Mary's University, San Antonio, Texas.

Hutchins, W. A.

1928 The Community Acequia: Its Origin and Development. The Southwestern Historical quarterly XXXI(3):261-284.

Ivey, J. E.

1973a Archaeological Investigations at the Mayer House (41 BX 326), San Antonio Texas. Center for Archaeological Research. The university of Texas at San Antonio, Archaeological Survey Report 59.

1978b Archaeological Investigations at the Gresser House, 41 BX 369 , San Antonio, Texas. Center for Archaeological Research, The university of Texas at San Antonio, Archaeological Survey Report 60 .

Ivey, J. E. and A. A. Fox

n.d. Archaeological Monitoring and Excavations at the Alamo PlazaRiver Linkage Project, San Antonio, Texas. Center for Archaeological Research, The University of Texas at San Antonio. Manuscript in preparation. 
James, V. L.

1938 Frontier and Pioneer Recollections of Early Days in San Antonio and West Texas. Artes Graficas Press, San Antonio.

Katz, P. R.

19771975 Archaeological Investigations at 01d Ursuline Academy, San Antonio, Texas. Center for Archaeological Research, The University of Texas at San Antonio, Archaeological Survey Report 34.

1978 Archaeological and Historical Investigations in the Arciniega Street Area, Downtown San Antonio, Texas. Center for Archaeological Research, The University of Texas at San Antonio, Archaeological Survey Report 61.

Kove T, R. M. and T. H. Kove1

1953 Dictionary of Marks, Pottery and Porcelain. Crown Publishers, Inc., New York, Reprint 1971.

Lomax, L.

1948 San Antonio River. Naylor, San Antonio, Texas.

Maverick, M. A.

1921 Memoirs of Mary A. Maverick. R. M. Green, ed., ATamo Printing Co., San Antonio.

Microfilm

n.d. City Engineer's Office, NCB 2548. San Antonio.

Munsey, C.

1970 The Illustrated Guide to Collecting Bottles. Hawthorn Books, Inc., New York.

01 msted, F. L.

1857 A Journey Through Texas, or a Saddle Trip on the Southwest Frontier. Dix, Edwards and Co., New York.

PuTlman, J. D.

1912 Historical Map of 01d San Antonio de Bexar.

Ramsde1 1, C.

1959 San Antonio, A Historical and Pictorial Guide. The University of Texas Press, Austin. 
Sanborn Insurance Company

1904 Maps of San Antonio, Texas. Sanborn Map Co., Volume I, New York.

Schuchard, E.

1951 100th Anniversary, Pioneer Flour Mills, San Antonio, Texas 1851-1951. Naylor, San Antonio.

Sorrow, W. M.

1972 Archeological Salvage Excavations at the Alamo (Mission San Antonio de Valero) 1970. Texas Archeological Salvage Project, The University of Texas at Austin, Research Report 4.

Toulouse, J. H.

1971 Bottle Makers and Their Marks. Thomas Nelson, Inc., New York.

Tunnel1, C. D. and W. W. Newcomb, Jr.

1969 A Lipan Apache Mission, Santa Lorenzo de 1a Santa Cruz, 1762-1771. Texas Memorial Museum Bulletin 14.

Valdez, F., Jr. and J. Eaton

1979 Preliminary Archaeological Investigations of Part of the San Pedro Acequia, San Antonio, Texas. Center for Archaeological Research, The University of Texas at San Antonio, Archaeological Survey Report 85. 

